\title{
A Proteogenomic Signature of Age-related Macular Degeneration in Blood
}

Valur Emilsson ${ }^{1,2, *}$, Elias F. Gudmundsson ${ }^{1}$, Thorarinn Jonmundsson ${ }^{1}$, Michael Twarog ${ }^{3}$, Valborg Gudmundsdottir ${ }^{1,2}$, Nancy Finkel ${ }^{3}$, Stephen Poor $^{3}$, Xin Liu ${ }^{3}$, Robert Esterberg ${ }^{3}$, Yiyun Zhang $^{3}$, Sandra Jose ${ }^{3}$, Chia-Ling Huang ${ }^{3}$, Sha-Mei Liao ${ }^{3}$, Joseph Loureiro ${ }^{3}$, Qin Zhang ${ }^{3}$, Cynthia L Grosskreutz ${ }^{3}$, Andrew A Nguyen ${ }^{3}$, Qian Huang ${ }^{3}$, Barrett Leehy ${ }^{3}$, Rebecca Pitts ${ }^{3}$, Brynjolfur G. Jonsson $^{1}$, Thor Aspelund ${ }^{1}$, John R. Lamb ${ }^{4}$, Fridbert Jonasson ${ }^{2,5}$, Lenore J. Launer ${ }^{6}$, Mary Frances Cotch $^{7}$, Lori L. Jennings ${ }^{3}$, Vilmundur Gudnason ${ }^{1,2}$ and Tony E. Walshe,

${ }^{1}$ Icelandic Heart Association, Holtasmari 1, IS-201 Kopavogur, Iceland.

${ }^{2}$ Faculty of Medicine, University of Iceland, 101 Reykjavik, Iceland.

${ }^{3}$ Novartis Institutes for Biomedical Research, 22 Windsor Street, Cambridge, MA 02139, USA. ${ }^{4}$ GNF Novartis, 10675 John Jay Hopkins Drive, San Diego, CA 92121, USA.

${ }^{5}$ Department of Ophthalmology, University Hospital, Reykjavik, Iceland.

${ }^{6}$ Laboratory of Epidemiology and Population Sciences, National Institute on Aging, MD, USA.

${ }^{7}$ Division of Epidemiology and Clinical Applications, National Eye Institute, National Institutes of Health, Maryland, USA.

*Correspondence: valur@hjarta.is and tony.walshe@ novartis.com 
medRxiv preprint doi: https://doi.org/10.1101/2021.07.27.21261194; this version posted July 30, 2021. The copyright holder for this preprint (which was not certified by peer review) is the author/funder, who has granted medRxiv a license to display the preprint in perpetuity.

It is made available under a CC-BY-NC-ND 4.0 International license .

\section{Abstract}

Age-related macular degeneration (AMD) is one of the most frequent causes of visual impairment in the elderly population. The overall etiology of AMD is complex and still poorly understood, though age, obesity, smoking, and high-density lipoprotein are known risk factors. In one of the first successful reported genome-wide association studies (GWAS), common genetic variants were strongly associated with AMD, including variants within the complement factor $\mathrm{H}(\mathrm{CFH})$ gene. To date, 34 genomic regions have been linked to AMD; however, the genes that mediate the risk remain largely unknown, indicating that novel approaches to identifying causal candidates are needed. Recent advances in proteomic technology have exposed the serum proteome's depth and complexity. In the Age, Gene/Environment Susceptibility Reykjavik Study (AGES-RS), a broad population-based study of the elderly $(\mathrm{N}=$ 5764), levels of 4137 human serum proteins and associated networks were integrated with established genetic risk loci for AMD, revealing many predicted as well as novel proteins and pathways, linked to the disease. Serum proteins were also found to reflect AMD severity independent of genetics and predict progression from early to advanced AMD after five years in this population. A two-sample Mendelian randomization study of five proteins associated with AMD found CFHR1, CFHR5, and FUT5 to be causally related to the disease, all of which were directionally consistent with the observational estimates. This study provides a robust and unique framework for elucidating the pathobiology of AMD. 
medRxiv preprint doi: https://doi.org/10.1101/2021.07.27.21261194; this version posted July 30, 2021. The copyright holder for this preprint (which was not certified by peer review) is the author/funder, who has granted medRxiv a license to display the preprint in perpetuity.

It is made available under a CC-BY-NC-ND 4.0 International license .

\section{Introduction}

AMD is a progressive late-onset disease that primarily affects the macular area of the retina and is a common cause of permanent loss of vision in the elderly population ${ }^{1}$. The clinical hallmark of early AMD is an accumulation of extracellular protein and lipid containing deposits between the retinal pigment epithelium (RPE) and Bruch's membrane, termed drusen. Advanced AMD can be either neovascular (nAMD) associated with blood vessel growth and leakage, or geographic atrophy (GA/Dry AMD) characterized by patches of retinal pigment epithelial (RPE) cell and photoreceptor cell loss in the macula. Anti-VEGF therapy is highly effective in controlling the abnormal vessel growth and leakage in nAMD; however, the disease nevertheless progresses and by 7 years, $98 \%$ of nAMD patients have atrophy ${ }^{2}$. Patients with GA have marked visual disability with relentless visual deterioration and progression to legal blindness. There are currently no approved therapies for GA or early $\mathrm{AMD}^{3,4}$. Elucidation of AMD pathobiology and identification of modifiable targets are critical for identifying clinically relevant biomarkers and designing therapeutics.

The first common genetic risk factor reported for AMD was the missense variant rs1061170 in CFH at chromosome $1 \mathrm{q} 31.3^{5-8}$. Many genes encoding other proteins involved in the complement cascade reside within the 1q31.3 region, including complement factors $\mathrm{H}$ related to 1 to 5 (CFHR1-5). Two independent variants at 1q31.3, rs1061170 and intronic variant rs1410996, account for $17 \%$ of AMD risk ${ }^{9}$. In the most recent GWAS examining 16,144 patients with advanced AMD, 52 independent variants were found at 34 different genomic loci explaining $46.7 \%$ of the variability in $\mathrm{AMD}$ risk $^{10}$. The risk variants with the largest difference between late AMD patients and healthy controls reside within the ARMS2/HTRA1 and $C F H$ genomic loci, 
medRxiv preprint doi: https://doi.org/10.1101/2021.07.27.21261194; this version posted July 30, 2021. The copyright holder for this preprint (which was not certified by peer review) is the author/funder, who has granted medRxiv a license to display the preprint in perpetuity. It is made available under a CC-BY-NC-ND 4.0 International license .

although for most variants, the effect size was small ${ }^{10}$. While some known AMD causal candidates are found at these genomic risk locations, the vast majority are yet to be identified.

Proteins are undeniably the key players in all life processes, with changes in their function and/or regulation influencing disease and well-being. As a result, changes in protein regulation and function, as well as their related networks, are most likely to mediate the genetic risk of complex diseases $^{11,12}$. Serum proteins have the desired attributes required for a comprehensive and unified approach to measuring an individual's global molecular status, as they capture information across many tissues and show a direct link to disease-related molecular pathways and activities ${ }^{11,12}$. Furthermore, serum proteins participate in cross-tissue regulatory loops, and therefore tissue specific disease progression emerges from an integration of local and systemic signals ${ }^{12}$. Recent developments in high-throughput measurements of thousands of proteins in a single sample have aided this work ${ }^{11,13-15}$, and aptamer-based affinity methods in particular, have been a driver of recent discoveries ${ }^{11,16-19}$. In this study, the serum levels of 4137 proteins measured in 5457 individuals from the prospective population-based AGES-RS were examined for association to different stages of AMD, disease progression, and the extent to which they mediated the genetics of the disease.

\section{Results}

\section{Analysis of 4137 proteins in circulation found 28 proteins associated with various stages of}

AMD. Descriptive statistics on the data linked to AMD in the 5457 person AGES-RS cohort ages 67 years and older (mean age $76.6 \pm 5.6$ years; $57.3 \%$ female) are shown in Supplementary Table S1. Using sex- and age-adjusted logistic regression analysis and two distinct definitions of earlystage AMD (Methods), we discovered that 28 serum proteins were associated with different stages of AMD using a study-wide significance threshold (Table 1, Figure 1a-c, Supplementary 
medRxiv preprint doi: https://doi.org/10.1101/2021.07.27.21261194; this version posted July 30, 2021. The copyright holder for this preprint (which was not certified by peer review) is the author/funder, who has granted medRxiv a license to display the preprint in perpetuity. It is made available under a CC-BY-NC-ND 4.0 International license .

Figure S1a-c, and Supplementary Tables S2-3). Some of these proteins were only related to AMD's early or late stages, like CEBPB and CFHR5, respectively (Figure 1d, e), while proteins such as FUT5 was associated with all stages of AMD (Figure 1f). We further stratified or combined late AMD into GA or nAMD and compared protein quintiles of all AMD-associated proteins with the various AMD-related outcomes. Levels of some AMD-associated proteins, such as CFHR1, BPIFB1, and CFHR5, increased almost continuously from no AMD to advanced nAMD (Supplementary Figure S2a-c). Supplementary Figure S3 depicts the distribution and relationship between the different quintiles of the 28 AMD-associated protein levels and the various AMD-related outcomes. In Supplementary Figure S4, the serum protein levels at the extreme end of the distribution, that is between the 5th and 1st quintiles using the first quintile as a reference (Methods), are shown in relation to the different AMD related outcomes. Again, it is evident that while some proteins were associated with all AMD stages (e.g., CFHR1, NDUFS4), some were more, or only associated with early (e.g., LINGO1, RAB17) or late-stage AMD (e.g., BIRC2) (Supplementary Figures S3 and S4). Finally, using single point sex and age-adjusted logistic regression analysis, we examined which if any of the 4137 proteins anticipated advancement to late AMD (pure GA or nAMD) while still in early AMD in the same people over a 5-year follow-up period. Only a single protein, PRMT3, showed significantly $\left(\mathrm{OR}=1.88, \mathrm{P}=5.3 \times 10^{-6}\right)$ increased levels in early $\mathrm{AMD}$ at the baseline exam and prior to progression to pure GA at follow-up, after adjusting for multiple comparisons (Figure 1g). No baseline protein changes predicted advancement of early AMD to nAMD between baseline and five-year follow-up.

Network-based approaches recognize that complex diseases arise from multiple proteins, genetic and environmental factors interacting in complex ways, rather than by single proteins that 
medRxiv preprint doi: https://doi.org/10.1101/2021.07.27.21261194; this version posted July 30, 2021. The copyright holder for this preprint (which was not certified by peer review) is the author/funder, who has granted medRxiv a license to display the preprint in perpetuity. It is made available under a CC-BY-NC-ND 4.0 International license .

function alone ${ }^{11,12,20-24}$. The first comprehensive serum protein network, closely linked to many common diseases and under genetic control, has recently been identified ${ }^{11}$. This work showed that serum proteins exist in 27 coregulatory network modules, most of which are arranged in larger clusters. Many of the 28 AMD-associated proteins were correlated to each other (Supplementary Figure S5). In fact, 12 of these 28 proteins were enriched in a single module of the serum protein network $\left(\mathrm{P}=2.6 \times 10^{-8}\right)$ (Figure 1 h and Supplementary Table S4). This module, known as serum protein module 13 (PM13), was not associated with any of the cardiometabolic traits previously examined ${ }^{11}$. However, the Eigenprotein (the first principal component) of PM13 was significantly associated with incidence of advanced AMD (nAMD, $n=$ $150, \mathrm{P}<0.001$ ) diagnosed five years after the first visit (Figure 1i), highlighting the potentially predictive nature of the network as previously stated ${ }^{11}$.

Serum proteins are present in distinct network modules that included proteins synthesized in all solid tissues and may serve as an integration of the body's tissue-specific networks. This extends to AMD in that single-cell RNA sequencing analysis (Supplementary Figure S6), shows many AMD-related proteins were abundantly expressed in AMD-relevant ocular cells, whereas others were enriched in tissues such as the liver and brain (Supplementary Table S5).

\section{Proteins in circulation and their co-regulatory networks elucidate the genetic basis of}

advanced AMD. In the most recent GWAS meta-analysis of advanced AMD, Fritsche et al. ${ }^{10}$ examined 16,144 AMD patients, identifying 52 independent common and rare variants across 34 distinct genomic loci (Supplementary Table S6). We tested each of these variants for an effect on the 4137 proteins with the aim to narrow down the causal candidates at these genetic risk loci. Here, 18 of the risk loci for AMD affected a total of 339 serum proteins (Supplementary Tables S6 and S7). In addition, the variant rs11080055 was linked to the previously described ${ }^{11}$ hotspot 
medRxiv preprint doi: https://doi.org/10.1101/2021.07.27.21261194; this version posted July 30, 2021. The copyright holder for this preprint (which was not certified by peer review) is the author/funder, who has granted medRxiv a license to display the preprint in perpetuity.

It is made available under a CC-BY-NC-ND 4.0 International license .

rs $704\left(r^{2}=0.784\right)$ that affected several hundred serum proteins (Supplementary Tables S6 and S8). Intriguingly, 22 out of 28 proteins found to be associated with AMD above were controlled by one or more of six AMD susceptibility variants (Table 2).

The AMD associated variant rs10922109 in the $C F H$ gene at 1q31.3, for example, was significantly associated with AMD in the AGES-RS $\left(\mathrm{P}=2.6 \times 10^{-16}\right)($ Supplementary Table S6) and influenced the levels of 40 serum proteins (Figure 2a and Supplementary Table S7), including the AMD-associated proteins CFHR1, TST, DLL3, ST6GALNAC1, CFP and NDUFS4 (Figure 2a, Table 1 and Supplementary Table S7). Among the proteins regulated by rs10922109, complement system proteins are significantly over-represented (Supplementary Table S9). These included the cis (proximal) regulated proteins CFHR1, CFHR4 and CFH (Figure 2b-d), as well as the trans (distal) regulated proteins C3, CFP (Figure 2e), and CFB. According to the GTEx database ${ }^{25}$, rs10922109 affects the mRNA levels of the genes encoding the cis regulated CFHR1, CFHR4 and CFH (Supplementary Figure S7a), with directionally consistent effects on the transcripts and cognate proteins (Supplementary Figure S7a, b). CFHR4 and CFH were not significantly associated with AMD using stringent multiple testing corrections, though the risk allele effect was directionally consistent with increased complement activation in AMD, with their relationships seen using the top and bottom quintiles and various stages of AMD (Figure 2b). Notably, CFH and the trans regulated protein CFP exhibit an inverse relationship with AMD outcomes compared to the CFHR1 and CFHR4 (Figure 2b). C3 and CFB, the two trans regulated proteins, were not linked to any AMD-related outcomes (data not shown). Finally, out of the 40 proteins regulated by rs10922109, 11 proteins cluster in protein module PM13 noted above (Supplementary Tables S10 and S11). 
medRxiv preprint doi: https://doi.org/10.1101/2021.07.27.21261194; this version posted July 30, 2021. The copyright holder for this preprint (which was not certified by peer review) is the author/funder, who has granted medRxiv a license to display the preprint in perpetuity.

It is made available under a CC-BY-NC-ND 4.0 International license .

Previously, we demonstrated that protein networks were under strong genetic control and that networks link genetics to complex diseases ${ }^{11}$. Consequently, we looked at the relationship between all known AMD-related GWAS variants and the 27 serum protein network modules through their Eigenproteins ( $1^{\text {st }}$ and $2^{\text {nd }}$ principal components). The modules in supercluster III (modules PM11 to PM15) ${ }^{11}$, were associated with the largest number of AMD-causing genetic variants (Supplementary Tables S12). For example, the $C F H$ variant rs570618 at 1q31.3 associated with AMD risk (Supplementary Tables S6), controls 217 different serum proteins of which 100 are found in PM13 (Supplementary Tables S7 and S10). Also, rs570618 was significantly associated with the Eigenprotein for the AMD-associated protein module PM13 (Supplementary Table S12), further reinforcing its connection to AMD. In passing, rs570618 influenced 33 of the 40 proteins affected by rs10922109 (see above) and are both intronic SNPs in the $C F H$ gene in a moderate linkage disequilibrium $\left(r^{2}=0.41\right)$, but the latter also regulated 184 other serum proteins (Supplementary Table S7).

Serum proteins regulated by AMD-associated genetic variants map to core pathways involved in the pathobiology of $A M D$. In a recent review of the pathobiology of AMD, a comprehensive pathway map of the disease based on 110 high-risk candidate genes, was presented ${ }^{26}$. Many of the proteins regulated by AMD-associated variants (Supplemental Tables S7 and S8) map to these pathways, including CFH, C2, CFB, C3, CFI, PILRA and PRLR, all of which are involved in para-inflammation homeostatic processes. Others include MUC1, TIMP3, and TNXB, which are involved in extracellular matrix (ECM) homeostasis, VEGFA, involved in choroidal homeostasis, and ICAM3, in phagocytosis. VEGFA, a promoter of neo-angiogenesis, for example, is increased in the ocular tissues of nAMD patients ${ }^{27}$. Drusen, accumulating under the retina in $\mathrm{AMD}$, are comprised of lipoprotein particles and a variety of proteins ${ }^{28}$, including 
medRxiv preprint doi: https://doi.org/10.1101/2021.07.27.21261194; this version posted July 30, 2021. The copyright holder for this preprint (which was not certified by peer review) is the author/funder, who has granted medRxiv a license to display the preprint in perpetuity. It is made available under a CC-BY-NC-ND 4.0 International license .

TIMP3, CLU, VTN, in addition to complement system proteins ${ }^{29-31}$, many of which are regulated by the AMD-associated risk variants studied here (Supplementary Tables S6-8). For example, the CETP intron variant rs 1864163 controlled 9 proteins, 2 of which were apoproteins (APOA5 and APOM), while rs17231506 (upstream of CETP, $r^{2}=0.14$ with rs1864163) controlled 10 proteins, 3 of which were apoproteins (APOA5, APOM and APOC3). These findings are consistent with the response to retention hypothesis of $\mathrm{AMD}^{32}$. The AMD variant rs570618 in the $\mathrm{CFH}$ gene regulates CLU which is one of the most prominent proteins in drusen, and it is substantially increased in advanced $\mathrm{AMD}^{33}$. When the top and bottom quintiles for CLU were compared to different AMD outcomes, we found that serum CLU levels were highest in AMD with GA (Figure 3a), which is consistent with the increased levels associated with the rs570618 AMD risk allele.

Our findings point to both previously implicated pathways, but also a slew of novel AMDassociated proteins and pathways. Inflammation and microglia cell recruitment has been linked to the pathophysiology of AMD, specifically retinal neovascularization ${ }^{34}$. The microglia associated proteins TREM2 (Figure 3b) and AIF1 (Figure 3c), were found to be controlled by the AMD risk variant and trans hotspot rs11080055 in the VTN/TMEM97 locus (Supplementary Tables S8). The serum level of the microglia and macrophage activity biomarker TREM2 ${ }^{35}$, previously linked to Alzheimer's disease ${ }^{36}$, was positively correlated with nAMD and not GA (Figure 3b), implying increased macrophage (and/or microglia) activity associated with neovascularization in AMD patients' retinas. AIF1 serum levels, like TREM2, were positively associated with an increased risk of AMD (Figure 3c). Another novel connection with AMD is SLC5A8 (aka SMCT1), a Na+-coupled transporter located in the retina ${ }^{37}$ that plays a role in the retina's energy homeostasis. SLC5A8 is notable for its ability to transport 2-oxothiazolidine-4- 
medRxiv preprint doi: https://doi.org/10.1101/2021.07.27.21261194; this version posted July 30, 2021. The copyright holder for this preprint (which was not certified by peer review) is the author/funder, who has granted medRxiv a license to display the preprint in perpetuity. It is made available under a CC-BY-NC-ND 4.0 International license .

carboxylate (OTC), a prodrug that can protect against oxidative stress, across the retina ${ }^{38}$. This protein was found to be regulated by two AMD-associated variants, rs2070895 and rs2043085 in or proximal to the $L I P C$ gene (Supplementary Table S7 and Figure 3d), as well as the $A P O B$ intron variant rs2678379 (Figure 3d), which is a well-established regulator of plasma lipoprotein levels (HDL, LDL, and triglycerides) ${ }^{39}$. The genetic influence and disease association show that serum levels of SLC5A8 are inversely related to AMD (Figure 3e), which is consistent with the protein's proposed protective function ${ }^{37}$. In summary, these findings indicate that serum proteins link genetics to the central molecular pathology of AMD in the retina.

Among the proteins affected by AMD-associated variants, categories such as the complement system, innate immunity, cell death and lipoprotein fractions, previously linked to AMD pathology ${ }^{26}$, were significantly enriched (Supplementary Tables S9). Proteins not previously implicated in the pathophysiology of AMD included five proteins that were regulated by rs72802342 in the CTRB2/CTRB1 locus, enriched for pancreatic secretion $\left(\mathrm{P}=1.4 \times 10^{-8}\right)$ (Supplementary Table S9). No other proteins were affected by this variant. These five proteins have been associated with pancreatitis and/or pancreatic cancer and breakdown of the $\mathrm{ECM}^{40-43}$. In passing, ECM pathway dysregulation is a known risk factor for $\mathrm{AMD}^{10}$. Finally, we find that the 339 proteins controlled by AMD risk loci (Supplementary Tables S3), were over-represented in the serum protein network PM13 and the interconnected larger cluster of modules PM11, PM14 and PM15 (Supplementary Table S12), all of which are to some extent regulated by the CFH locus. The inclusion of proteins regulated by the trans hotspot rs11080055, located at the VTN/TMEM97 locus, in the immune and inflammation related cluster of modules has been previously reported $^{11}$. It should be noted though, that rs 11080055 only accounts for a very small portion of AMD's genetic liability (Supplementary Table S6). 
medRxiv preprint doi: https://doi.org/10.1101/2021.07.27.21261194; this version posted July 30, 2021. The copyright holder for this preprint (which was not certified by peer review) is the author/funder, who has granted medRxiv a license to display the preprint in perpetuity.

It is made available under a CC-BY-NC-ND 4.0 International license .

\section{Identifying causal candidate proteins for AMD using two-sample Mendelian randomization}

analysis. To determine if any of the 28 AMD-associated proteins might be causally related to the disease, a two-sample Mendelian randomization (MR) study was performed using cis-acting genetic variants as instruments. BPIFB1, CFHR1, CFHR5, FUT5, and GHR were found to have such instruments. The causal estimate for each protein was determined using the generalized least squares method (GWLS) ${ }^{44}$, where CFHR1, CFHR5 and FUT5 were found to be significant (FDR < 0.05) (Figure 4). For both definitions of AMD (see Methods), the proteins CFHR1, CFHR5, and FUT5 were found to be significant and directionally consistent with their corresponding observational estimates (Figure 4), highlighting their role as risk factors for AMD development. Of the three proteins, CFHR1 was detected with ELISA in a much smaller sample of an independent study of healthy volunteers and AMD patients, confirming elevated circulating levels of CFHR1 in the disease's most advanced stage (Supplementary Figure S8 and Methods). In a secondary analysis, we repeated the MR analysis, but this time we included all 1327 aptamers with cis-acting genetic instruments. In this study, 21 additional proteins, such as ADAM19, C3, CFI, AIF1, and VTN, were found to have a significant causal estimate for AMD (Supplementary Figure S9). These proteins were collectively enriched for the complement and coagulation cascade $(F D R=0.00002)$. Different aptamers for C3 and VTN produced opposite effects, potentially due to aptamers binding different protein epitopes or isoforms (Supplementary Figure S9). Both CFHR1 and FUT5 remained statistically significant at this more stringent multiple testing correction threshold (Supplementary Figure S9).

\section{Discussion}

Homeostasis, the maintenance of a global state, has long been recognized as a property of living systems and is maintained by integrating local and global signals so that each tissue does not act 
medRxiv preprint doi: https://doi.org/10.1101/2021.07.27.21261194; this version posted July 30, 2021. The copyright holder for this preprint (which was not certified by peer review) is the author/funder, who has granted medRxiv a license to display the preprint in perpetuity. It is made available under a CC-BY-NC-ND 4.0 International license .

independently, but rather influences and responds to dynamically preserve the biologic equilibrium. The measurement of the levels of thousands of proteins in serum of thousands of individuals has begun to illuminate the process by which homeostasis may occur ${ }^{11,12,17}$. In this study we document how serum proteins report on and influence AMD appearance and progression in the eye. Previous studies of AMD patient plasma and urine reveal changes in lipid and energy metabolites however sample size has limited detection of serological protein changes, or stratification of late AMD into GA and nAMD ${ }^{45-50}$. The population-based AGES study with its array of biomarkers, clinical profiles, and genetic risk factors collected prospectively from participants who were aged $>67$ at baseline visit, and a follow up visit after five-years has enabled us to identify circulating proteins and protein networks in patients that associate with AMD stage and progression.

Consistent with the known links between AMD and the complement pathway, three complement pathway proteins were associated with AMD (CFHR1, CFHR5 and CFP). Six additional proteins known to modulate both the innate and adaptive immune response were also associated with AMD (TNFRSF14, CCL1, CXCL17, BPIFB1, BIRC2 and CEBPB), implicating broad induction of inflammatory processes in AMD. Reductions in two mitochondrial proteins, the complex 1 protein NDUFS4 and the sulfotransferase protein TST were also associated with AMD, consistent with structural, functional, and genetic mitochondrial changes in AMD ${ }^{51-55}$. Inactivation of the NDUFS4 gene causes a severe form of the blinding disease Leigh syndrome, and mice lacking this gene die prematurely at 50-60 days old ${ }^{56}$, with compromised photoreceptor function $^{57}$ and excessive lipid droplet formation ${ }^{58}$. Elevation of the ribosomal S6 protein kinase 1 (RPS6KB1), a component of the nutrient-responsive mTOR (mammalian target of rapamycin) signaling pathway was also associated with AMD, consistent with the AMD-like phenotype in 
medRxiv preprint doi: https://doi.org/10.1101/2021.07.27.21261194; this version posted July 30, 2021. The copyright holder for this preprint (which was not certified by peer review) is the author/funder, who has granted medRxiv a license to display the preprint in perpetuity.

It is made available under a CC-BY-NC-ND 4.0 International license .

mice with RPE mTOR overactivation ${ }^{59-61}$. The pro-longevity effects of RPS6KB1 gene deletion $^{62}$, or mTORC1 inhibition across multiple species ${ }^{63}$, are also intriguing when considering AMD as a disorder of aging.

The rate of progression from early to late AMD was $\sim 4.5 \%$ per year, with $12.7 \%$ progressing to GA and $7.6 \%$ to nAMD after 5 years. Serum levels of PRMT3 protein were elevated in early AMD patients progressing to GA, but not in those progressing to nAMD. PRMT3 controls ribosomal activity via arginine methylation of the $40 \mathrm{~S}$ ribosomal subunit protein RPS2 ${ }^{64-66}$. Interestingly, control of mRNA translation is via phosphorylation of another component of the 40S ribosomal subunit, RPS6, by the previously mentioned kinase RPS6KB1, whereas another ribosomal 40S subunit RPS10 was controlled by the AMD-associated variants rs570618 and rs429358. Alterations in post-translational regulation of protein synthesis by both phosphorylation and methylation could be a key early driver of AMD pathogenesis. We also examined the association of protein networks with AMD, since deep profiling has revealed the modular structure of the serum proteome containing 27 distinct protein modules ${ }^{11}$. Interestingly, the protein module PM13 is linked to incident nAMD and is enriched with individual proteins linked to AMD (12 of 28) and/or proteins regulated by AMD risk variants. Serum protein network changes are highly predictive of overall survival and disease progression in complex diseases such as cardiovascular and metabolic diseases ${ }^{11}$, and these data demonstrate the ability of serum protein modules to also predict advanced AMD.

AMD is associated with 34 distinct genomic loci, accounting for nearly half of AMD's genetic liability ${ }^{10}$. Integrating intermediate traits such as mRNA and/or protein levels with genetics and disease traits helps in identifying the causal candidates ${ }^{11,21-24}$. The present study integrated the most recent findings of AMD genetic risk factors with 4137 human serum proteins, providing 
medRxiv preprint doi: https://doi.org/10.1101/2021.07.27.21261194; this version posted July 30, 2021. The copyright holder for this preprint (which was not certified by peer review) is the author/funder, who has granted medRxiv a license to display the preprint in perpetuity. It is made available under a CC-BY-NC-ND 4.0 International license .

mechanistic insights into previously described AMD SNPs. Many of the variants that explained the largest fraction of the genetic liability for AMD, regulated a wide range of circulating proteins. Interestingly, of the AMD-associated proteins identified, the majority were controlled by one or more of only six AMD susceptibility variants. For example, the $C F H$ variant rs $10922109(\mathrm{C})$, a strong risk factor for AMD (OR = 2.63), increases levels of the CFHR1 and CFHR4 proteins, while also decreasing $\mathrm{CFH}$. Consistent with these changes in protein levels, rs 10922109 (C) has previously been associated with activation of the complement cascade in AMD patients ${ }^{67}$ and also increased serum CFHR4 by orthogonal methods ${ }^{68}$. AMD variants had both overlapping and distinct effects on serum proteins and controlled numerous proteins in the complement cascade. For instance, the $C F H$ variant rs570618 influenced 33 of the 40 proteins affected by the co-localized variant rs10922109 (e.g., CFHR1/4, C3, CFB and CFP), but rs570618 also regulated 184 other serum proteins (e.g., CFHR5, C1S and C8) (Supplementary Table S7). It should be noted that the AMD risk allele for the rs570618 variant was not linked to higher levels of complement activation in AMD patients ${ }^{67}$ implicating non-complement pathways associated with this variant (Supplementary Table S9), or increased complement activity at ocular cell surfaces such as Bruch's membrane or choriocapillaries ${ }^{67}$.

Beyond complement, variant rs62358361 (G), located in an C9 intron, which is protective for AMD, significantly reduces CREBBP - the master regulator of hepatocyte lipid metabolism, implicating a potential role for liver metabolism pathways in AMD. In contrast to these strong genetic associations driving systemic protein changes, rs3750846 (OR 2.81) in the ARMS2/HTRA1 locus on chromosome 10 does not affect serum protein levels in the present study. One reason could be that the current platform lacks aptamers that detect the ARMS2 and HTRA1 proteins encoded by genes near rs 3750846 , but the variant is known to regulate the 
medRxiv preprint doi: https://doi.org/10.1101/2021.07.27.21261194; this version posted July 30, 2021. The copyright holder for this preprint (which was not certified by peer review) is the author/funder, who has granted medRxiv a license to display the preprint in perpetuity. It is made available under a CC-BY-NC-ND 4.0 International license .

transcription of both ARMS 2 and HTRA1 in solid tissues ${ }^{69}$. Alternatively, this variant may alter ocular specific protein changes that are not apparent in serum.

CFHR1 and CFHR5 are presumed pathogenic since they impede CFH binding to proinflammatory lipid peroxidation products ${ }^{70,71}$, and induce inflammasome activation ${ }^{72}$, whereas CFHR1 gene deletion is known to be protective for $\mathrm{AMD}^{70}$. Indeed, the two-sample MR test analysis revealed that both proteins could be causally linked to AMD. However, because their cis regions overlap (Supplementary Table S7), from which the genetic instruments are selected, it is impossible to say whether one or both are the causal effector. In addition, the FUT5 was supported as causal candidate in the MR analysis, which was also strongly associated with risk of AMD (Table 1). As 23 of the AMD-associated proteins did not have any cis-acting instruments, they could not be tested in the MR analyses, and we thus cannot exclude their candidacy as causal proteins. In the extended MR analysis, 21 additional proteins were supported as causal, including multiple other members of the complement system (CFI, C3, C1R, F11, VTN), further highlighting the causal role of this pathway in the development of AMD.

AMD is a multifactorial age-related disease with a complex pathobiology in which systemic and local inflammatory and other effectors play significant roles. Recent evidence indicates that thousands of proteins present in serum participate in cross tissue regulation that connects all parts of the body ${ }^{11,12}$. This occurs by tissues releasing protein(s) into the bloodstream which control biological processes in other physically distant tissues, resulting in a network of cross-tissue regulatory loops $^{12}$. For example, the expression of the proteins CFHR1 and CFHR5, which have been causally linked to AMD in this study (Figure 4), are highly specific to the liver, whereas FUT5 is expressed in the bone marrow and testis (Supplementary Table S5). More research is required to determine the roles of the numerous serum proteins discussed in this study and their 
potential effect on various pathophysiological processes that lead to various stages of AMD in the local eye setting. Many of the serum proteins associated with AMD in this study are characterized as intracellular proteins, and the significance of their presence in serum, remains to be determined. Our findings provide a robust framework for understanding the pathobiology of AMD, which may lead to the discovery of new systemic biomarkers and therapeutic targets. 
medRxiv preprint doi: https://doi.org/10.1101/2021.07.27.21261194; this version posted July 30, 2021. The copyright holder for this preprint (which was not certified by peer review) is the author/funder, who has granted medRxiv a license to display the preprint in perpetuity.

\section{Methods and Material (online content)}

Study population. Participants aged 66 through 96 were from the Age, Gene/Environment Susceptibility Reykjavik Study (AGES-RS) cohort $^{73}$. AGES-RS is a single-center prospective population-based study of deeply phenotyped subjects (5764, mean age $76.6 \pm 5.6$ years) and survivors of the 40-year-long prospective Reykjavik study (n 18,000), an epidemiologic study aimed to understand aging in the context of gene/environment interaction by focusing on four biologic systems: vascular, neurocognitive (including sensory), musculoskeletal, and body composition/metabolism. Descriptive statistics of this cohort as well as detailed definition of the various disease endpoints and relevant phenotypes measured have been published ${ }^{11,73}$. Of the 5764 AGES-Reykjavik participants 3411 attended a 5-year follow-up visit (AGES-RS II). The AGES-RS was approved by the NBC in Iceland (approval number VSN-00-063), and by the National Institute on Aging Intramural Institutional Review Board, and the Data Protection Authority in Iceland.

Detailed description of AMD diagnosis and the baseline characteristics of the AMD population in AGES-RS has previously been described in two separate publications ${ }^{74,75}$, which vary in terms of the medical definition of early stage AMD. In Holliday et al. ${ }^{75}$, early stage AMD $(n=1755)$ was defined as the presence of soft drusen $(>63 \mu \mathrm{m})$ alone, retinal pigment epithelium (RPE) depigmentation alone or a combination of soft drusen with increased retinal pigment and/or depigmentation in the absence of late AMD, while Jonasson et al. ${ }^{74}$ defined early AMD $(\mathrm{n}=$ 1054) by the presence of any soft drusen and pigmentary abnormalities (increased or decreased retinal pigment) or the presence of large soft drusen $\geq 125 \mu \mathrm{m}$ in diameter with a large drusen area $>500 \mu \mathrm{m}$ in diameter, or large $\geq 125 \mu \mathrm{m}$ indistinct soft drusen in the absence of signs of late $\mathrm{AMD}^{74}$. Late $\mathrm{AMD}(\mathrm{n}=272)$ was defined by the presence of any of the following: geographic 
medRxiv preprint doi: https://doi.org/10.1101/2021.07.27.21261194; this version posted July 30, 2021. The copyright holder for this preprint (which was not certified by peer review) is the author/funder, who has granted medRxiv a license to display the preprint in perpetuity. It is made available under a CC-BY-NC-ND 4.0 International license .

atrophy (GA) or exudative AMD including subretinal hemorrhage, subretinal fibrous scar, RPE detachment, or serous detachment of the sensory retina or signs of treatment for neovascular $\mathrm{AMD}^{74}$. Also, early and late AMD was combined as AMD any. Late AMD was separated into GA pure $(n=112)$ or neovascular AMD (nAMD) pure $(n=160)$, but was also combined for any form of GA as GA + nAMD ( $n=183)$. We used both medical definitions of early AMD (and AMD any) separately to analyze the association of serum proteins with AMD.

Protein measurements via SOMAmers. For the AGES-RS, we used a distinct version of the SomaScan platform (Novartis V3-5K), based on the slow-off rate modified aptamer (SOMAmer) protein profiling technology ${ }^{11,12,76}$. The aptamers are small single-stranded 40-mer DNA oligomers with modified nucleic acids selected to specifically recognize target proteins in their native three-dimensional state and show slow dissociation kinetics $\left(\mathrm{t}_{1 / 2}>30 \mathrm{~min}\right)$ which in combination with stringent wash steps impedes nonspecific binding ${ }^{76}$. The custom-design SOMAscan platform was built to quantify 5034 protein analytes in a single serum sample with a focus on proteins that are known or expected to be present extracellularly or on the surface of cells, 4782 of which SOMAmers directly bind to 4137 different human proteins. Blood samples were collected at the AGES-RS baseline, after an overnight fast. Serum was prepared using a standardized protocol ${ }^{77}$, stored in $0.5 \mathrm{ml}$ aliquots at $-80^{\circ} \mathrm{C}$ and serum samples that had not been previously thawed were used for the protein measurements. To avoid batch or time of processing biases, the order of sample collection and processing for protein measurements were randomized and all samples run as a single set at SomaLogic Inc. (Boulder, US). All SOMAmers that passed quality control had median intra-assay and inter-assay coefficient of variation $(\mathrm{CV})<5 \%$ or equivalent to reported variability ${ }^{78}$. Various metrics, including both aptamer specificity direct tandem mass spectrometry (MS) analysis and inferential assistance using genetic analysis, have 
medRxiv preprint doi: https://doi.org/10.1101/2021.07.27.21261194; this version posted July 30, 2021. The copyright holder for this preprint (which was not certified by peer review) is the author/funder, who has granted medRxiv a license to display the preprint in perpetuity.

It is made available under a CC-BY-NC-ND 4.0 International license .

been used for the performance of the proteomic platform, suggesting strong target specificity throughout the platform ${ }^{11}$. Hybridization controls were used to correct for systematic variability in detection and calibrator samples of three dilution sets $(40 \%, 1 \%$ and $0.005 \%)$ were included so that the degree of fluorescence was a quantitative reflection of protein concentration. Box-Cox transformation was applied on the protein data $^{79}$, and extreme outlier values excluded, defined as values above the 99.5 th percentile of the distribution of 99th percentile cutoffs across all proteins after scaling, resulting in the removal of an average 11 samples per SOMAmer. Previous studies have shown that pQTLs replicate well across different study populations as well as proteomic platforms ${ }^{11,19}$. While a recent comparison of protein measurements across different platforms showed a wide range of correlations ${ }^{80}$, cis pQTLs detection and validation by orthogonal MSbased measures were predictive of a strong correlation across platforms and were great indicators of platform specificity when protein concentrations obtained by orthogonal methods differ. The aptamer specificity of six of the AMD-associated proteins listed in the main text has already been validated by orthogonal mass spectrometry (MS)-based approach and/or inferred measures by proximal cis variants assessment for SOMAmer-protein interactions ${ }^{11}$. Nine additional aptamers were confirmed with SOMAmer pull down and MS (SP-MS) using AMD patient serum samples (Supplementary Table S13). There are many reasons why some aptamer-enriched proteins are not detected by SP-MS. For instance, MS analyses have different sensitivity than that of SOMAmer scan and is dependent on the protein sequence. Factors such as ion suppression of individual peptides caused by instrument/interfering molecules, incomplete trypsin digestion, and modifications of peptides either naturally or artifactually can limit the detection. 
medRxiv preprint doi: https://doi.org/10.1101/2021.07.27.21261194; this version posted July 30, 2021. The copyright holder for this preprint (which was not certified by peer review) is the author/funder, who has granted medRxiv a license to display the preprint in perpetuity. It is made available under a CC-BY-NC-ND 4.0 International license .

Protein measurements via ELISA. Participants aged 55 and over (up to n=60, 15 per group), enrolled in a prospective study by Ophthalmic Consultants of Boston, to measure complement and disease-related protein biomarkers in blood. AMD patients with Age-Related Eye Disease Study (AREDS) ${ }^{81}$ grade 2-4 had best corrected visual acuity (BCVA) of at least 20/200. Healthy volunteers were aged matched (+/- 2 to AMD patients) with BCVA of 20/40 or better in both eyes, and a comprehensive eye examination within previous 12 months revealing no diagnosis other than refractive error, mild cataract, dry eye or AREDS grade 1. AREDS grading criteria for grade 2 included mild changes including multiple small drusen, non-extensive intermediate drusen, and/or pigment abnormalities. AREDS grade 3 included at least 1 large drusen of at least $125 \mu \mathrm{m}$ in diameter, extensive intermediate drusen, and/or noncentral geographic atrophy. AREDS grade 4 included advanced AMD central geographic atrophy in one or both eyes. Qualifying subjects completed an informed consent form, and no identifying patient information was included. A blood sample of 10 milliliters was collected by routine phlebotomy, in EDTAcoated, lavender-topped collection tubes. Plasma was isolated after centrifugation at 4,000 rpm for 30 minutes, frozen and stored at $-80^{\circ} \mathrm{C}$. Rabbits were immunized with recombinant human FHR1 protein at Covance (Princeton, NJ), and CFHR1 cross-reactive antibodies were purified from serum using CFHR1-conjugated CNBr-activated Sepharose 4B resin (Cytiva, Marlborough, MA). Additionally, antibodies showing cross-reactivity to Factor $\mathrm{H}$ were removed by several rounds of depletion using Factor H-conjugated resin. CFHR1 levels in patient plasma were measured in a Meso Scale Discovery assay (Rockville, MD) using the selective antibodies. Analysis of gene expression in single cell RNA sequencing data from eye tissues: Normalized single cell data was downloaded from GEO (GSE135922) and was analyzed with the R package Seurat (v.3.0.0) in R 3.6.3 environment. Final dataset contained 4335 cells after filtering. 
medRxiv preprint doi: https://doi.org/10.1101/2021.07.27.21261194; this version posted July 30, 2021. The copyright holder for this preprint (which was not certified by peer review) is the author/funder, who has granted medRxiv a license to display the preprint in perpetuity.

It is made available under a CC-BY-NC-ND 4.0 International license .

Variable genes were identified using Seurat with default parameters and Principal Components Analysis (PCA) was performed on these variable genes. First 11 PCs of the single cell data (resolution $=0.2$ ) were used for clustering cells with similar gene expression profile. Clusters were identified using FindNeighbors and FindClusters functions from Seurat package and UMAP dimensionality reduction was utilized for cluster visualization. The cell clusters were then manually annotated based on the markers reported in the paper ${ }^{82}$.

Statistical and genetic analysis. We used linear or logistic regression for the associations of individual proteins as well as Eigenvectors of protein modules with various phenotypic measures, depending on the result being continuous or binary. Statistical results were obtained using linear models for continuous outcomes and generalized logistic models for binary outcomes for comparison of protein quintiles and AMD-related clinical traits. The models were fit using the outcome phenotypes as dependent variables and protein quintiles as predictor variables along with the adjustment variables age and sex. The protein quintiles were treated as factor variables to avoid underlying assumptions regarding linearity of effects. Continuous outcomes were standardized using z-scores prior to model fitting thus coefficient estimates should be interpreted on the standard deviation scale. That is an estimated mean difference of 1 between protein quintiles translates to a one-standard-deviation difference between groups after adjusting for other included variables. The expected means were obtained as linear predictions from the fitted models along with the fitted confidence intervals around the mean. The linear predictions for qualitative phenotypes are shown on the log-odds scale. The difference between the 5 th and 1 st protein quintiles was obtained as the expected marginal difference between those groups. Thus, for continuous outcomes, they are the optimal linear estimator with corresponding 
medRxiv preprint doi: https://doi.org/10.1101/2021.07.27.21261194; this version posted July 30, 2021. The copyright holder for this preprint (which was not certified by peer review) is the author/funder, who has granted medRxiv a license to display the preprint in perpetuity.

It is made available under a CC-BY-NC-ND 4.0 International license .

confidence intervals and P-values, but for discrete outcomes they are obtained using the commonly applied asymptotic approximations.

We applied linear regression using an additive genetic model for all single-point SNP association analyses for different disease-related outcomes. The results of associating genetic variants with serum protein levels were obtained using a GWAS of 4137 human proteins measured in serum using 7,506,463 assayed and imputed genetic variants from 5457 AGES-RS individuals ${ }^{83}$. All statistical analyses of the present study were conducted using the software environment $\mathrm{R}$ statistical package version 3.6.0 (2019-04-26).

Two-sample Mendelian randomization analysis. In a two-sample Mendelian randomization study, genetic variants for each trait, the protein-encoding gene (exposure) $X$ and AMD (outcome) $Y$ are found in two distinct samples. A genetic variant (SNP) $Z$ is used in the analysis provided it fulfills the three assumptions of instrumental variables:

1. There exists a significant association between SNP $Z$ and exposure $X$.

2. SNP $Z$ is independent of any confounder $U$ which might influence exposure $X$ and outcome $Y$.

3. SNP $Z$ is independent of outcome $\underline{Y}$ conditional on exposure $X$ and confounder $U$. This assumption is usually referred to as the exclusion criterion.

The first assumption is readily tested by setting a threshold on the significance level on the SNPexposure association. Unfortunately, it remains a challenge to examine the validity of the second and third assumptions. When a SNP violates the third assumption, we generally speak of pleiotropy. To obtain the SNP-exposure associations, all genetic instruments within a $1 \mathrm{Mb}( \pm$ $500 \mathrm{~kb}$ ) cis window for the protein-encoding gene were obtained for a given SOMAmer. A ciswindow-wide significance level $\mathrm{P}_{\mathrm{b}}=0.05 / \mathrm{N}$, where $\mathrm{N}$ was the number of SNPs within a given 
medRxiv preprint doi: https://doi.org/10.1101/2021.07.27.21261194; this version posted July 30, 2021. The copyright holder for this preprint (which was not certified by peer review) is the author/funder, who has granted medRxiv a license to display the preprint in perpetuity. It is made available under a CC-BY-NC-ND 4.0 International license .

cis-window, was computed. Genetic instruments within the cis window for each SOMAmer were then clumped such that variants in high linkage disequilibrium (LD) $\left(\mathrm{r}^{2} \geq 0.2\right)$ within a $1 \mathrm{Mb}$ region were combined. The list of variants was then further pruned by removing all instruments with $\mathrm{P} \geq \mathrm{P}_{\mathrm{b}}$.

Summary statistics on the genetic risk on AMD were obtained from a GWAS provided by the IAMDGC consortium $^{10}$. Any SNP in the $c$ is window-wide significant data set not found in the AMD GWAS data set were replaced by proxy SNPs $\left(r^{2}>0.8\right)$ when possible, to maximize SNP coverage. Causal estimate for each protein was obtained by the generalized weighted least squares (GWLS) method ${ }^{44}$, which accounts for the correlation that can exist between instruments. Let $Z=\{1,2, \ldots, M\}$ be an index set of all SNPs associated with a protein-encoding gene and AMD. For $j \in Z$, denote the $j$-th SNP-protein association and SNP-AMD association as $\beta_{X_{j}}$ and $\beta_{Y_{j}}$ respectively, each with their corresponding standard error $\sigma_{X_{j}}$ and $\sigma_{Y_{j}}$. Then, the causal estimate $\hat{\theta}$ is found by evaluating:

$$
\hat{\theta}=\left(\beta_{X}^{T} \Sigma^{-1} \beta_{X}\right)^{-1} \beta_{X}^{T} \Sigma^{-1} \beta_{Y}
$$

where $\beta_{X}=\left(\beta_{X_{1}}, \ldots, \beta_{X_{M}}\right)^{T}$ and $\beta_{Y}=\left(\beta_{Y_{1}}, \ldots, \beta_{Y_{M}}\right)^{T}$ and $\Sigma^{-1}$ is the inverse of the weighting matrix $\Sigma$ whose $(i, j)$-th entry is $\rho_{i j} \sigma_{Y_{i}} \sigma_{Y_{j}}$ and $\rho_{i j}$ is the correlation between SNPs $i, j \in Z$. The standard error of $\hat{\theta}$ is $\operatorname{se}(\hat{\theta})=\alpha \sqrt{\left(\beta_{X}^{T} \Sigma^{-1} \beta_{X}\right)^{-1}}$, where $\alpha=\max (1, \sqrt{M S E})$ with:

$M S E=\frac{\left(\beta_{Y}-\beta_{X} \widehat{\theta}\right)^{2}}{M-1}$,

reflects our uncertainty about the weights by assuming that we only know their relative magnitudes. 
medRxiv preprint doi: https://doi.org/10.1101/2021.07.27.21261194; this version posted July 30, 2021. The copyright holder for this preprint (which was not certified by peer review) is the author/funder, who has granted medRxiv a license to display the preprint in perpetuity.

It is made available under a CC-BY-NC-ND 4.0 International license .

Finally, each estimate was subjected to a two-step sensitivity analysis. Any protein with a causal estimate found to be significant after adjusting the P-value with the Benjamini-Hochberg method was reassessed with the weighted median estimator which allows for up to $50 \%$ of the genetic instruments to violate any of the three assumptions of instrumental variables ${ }^{84}$. If the direction of the weighted median estimator was consistent with the GWLS estimate and remained significant at $\mathrm{P}<0.05$ it was subjected to the second stage of the sensitivity analysis but otherwise removed. Any protein which passed the first step was then reexamined with MR-Egger estimator which replaces the exclusion criterion with a weaker condition, the InSIDE assumption ${ }^{85}$, which allows SNPs to exhibit pleiotropic effects provided that the pleiotropic effect is uncorrelated with the SNP-AMD effect $\beta_{Y_{j}}$. As with the first step, any protein whose MR-Egger estimate was directionally consistent with the GWLS estimate and significant at $\mathrm{P}<0.05$ was kept and considered a causal candidate. Causality for proteins with single cis-acting variants was assessed with the Wald ratio estimator $\hat{\theta}=\beta_{Y} / \beta_{X}$.

\section{Acknowledgements}

We thank the IAMDGC consortium for supplying us with their GWAS summary statistics data. The Age, Gene/Environment Susceptibility-Reykjavik Study (AGES-RS) was supported by NIH contracts N01-AG-1-2100 and HHSN27120120022C, the NIA Intramural Research Program, Hjartavernd (the Icelandic Heart Association), and the Althingi (the Icelandic Parliament). V.E. and Va.G. are supported by the Icelandic Research Fund (IRF grants 195761-051, 184845-053 and 206692-051). 
medRxiv preprint doi: https://doi.org/10.1101/2021.07.27.21261194; this version posted July 30, 2021. The copyright holder for this preprint (which was not certified by peer review) is the author/funder, who has granted medRxiv a license to display the preprint in perpetuity.

\section{Figure Legends}

Figure 1. Association of global serum proteins with different stages of AMD. a. Using

logistic regression analysis and Bonferroni correction for multiple comparisons, a volcano plot of all serum proteins associated with AMD early is shown, with colored data points highlighting significant associations. Definition of early-stage AMD was according to Holliday et al. ${ }^{75}$. b. A volcano plot of late stage AMD. c. Similar analysis and representive volcano plot for AMD any, where early-stage of the disease was defined according to Holliday et al. ${ }^{75}$. d. Relationship between the top and bottom quintiles for serum CEBPB levels and AMD-related outcomes. $* * *(\mathrm{P}-\mathrm{value}<0.001), * *(\mathrm{P}-\mathrm{value}<0.01), *(\mathrm{P}$-value $<0.05)$. e. Similar relationship shown for CFHR5, ***(P-value < 0.001), **(P-value < 0.01), *(P-value < 0.05) and f. FUT5, ***(P-value $<0.001), * *(\mathrm{P}$-value < 0.01), *(P-value < 0.05). g. Raised PRMT3 levels in those with early AMD and who develop pure geographic atrophy (GA/Dry AMD) five years later (P-value $=$ $\left.5.3 \times 10^{-6}\right)$. h. Venn diagram showing significant enrichment $(12$ out of 28 proteins, $\mathrm{P}-\mathrm{value}=$ $2.6 \times 10^{-8}$ ) of the AMD-associated proteins in the previously described serum protein module $\mathrm{PM}_{13}{ }^{11}$. FET; Fisher exact test. i. Using logistic regression analysis, the Eigenprotein for PM13 was found to be significantly associated with incident nAMD $\left(\mathrm{P}-\mathrm{value}=1.2 \times 10^{-11}\right)$, diagnosed five years after the baseline visit. $* * *(\mathrm{P}$-value $<0.001)$.

Figure 2. Serum proteins link genetics to AMD. a. The AMD-related variant rs10922109 at 1q31.3 is connected to 40 serum proteins in a Circos plot (see also Supplementary Table S7).

The blue (trans effects) and red (cis effects) colored proteins are among the 28 AMD-associated proteins in Table 1. b. Box plot showing serum levels of CFHR1 as a function of copy C alleles for the variant rs10922109 (left panel). The relationship between the $5^{\text {th }}$ and $1^{\text {st }}$ quintile (reference) of CFHR1 serum levels and various AMD related outcomes, ***(P-value < 0.001), 
medRxiv preprint doi: https://doi.org/10.1101/2021.07.27.21261194; this version posted July 30, 2021. The copyright holder for this preprint (which was not certified by peer review) is the author/funder, who has granted medRxiv a license to display the preprint in perpetuity. It is made available under a CC-BY-NC-ND 4.0 International license .

$* *(\mathrm{P}$-value < 0.01), *(P-value < 0.05). c-e. Similar plots for CFHR4, CFH and CFP. ***(P-value $<0.001), * *(\mathrm{P}-$ value $<0.01), *(\mathrm{P}-$ value $<0.05)$

Figure 3. Proteins involved in various AMD-related core pathologies are linked to AMD risk variants. a. Box plot showing serum levels of CLU as a function of copy $\mathrm{T}$ alleles for the variant rs570618 (left panel). The relationship between the $5^{\text {th }}$ and $1^{\text {st }}$ quintile (reference) of CLU serum levels and various AMD related outcomes, $* * *(\mathrm{P}$-value $<0.001), * *(\mathrm{P}$-value $<0.01), *(\mathrm{P}-$ value $<0.05)$. b-c. Similar plots for TREM2 and AIF1 with copy C allele for rs11080055. ***(Pvalue $<0.001), * *(\mathrm{P}$-value $<0.01), *(\mathrm{P}$-value $<0.05)$. d. The Manhattan plot highlights transacting variants at different chromosomes in a GWAS of serum SLC5A8 levels, specifically the AMD-associated variants rs2070895 and rs2043085, as well as the variant rs2678379, which affects lipoprotein levels. The $y$-axis shows the $-\left(\log _{10}\right)$ of the P-values for the association of each genetic variant present along the x-axis at different chromosomes. e. A box plot (left panel) of the AMD-associated variant rs2043085 affecting serum levels of SLC5A8 $\left(\mathrm{P}=2 \times 10^{-13}\right)$, and the relationship of the $5^{\text {th }}$ and $1^{\text {st }}$ (reference) quintiles of SLC5A8 levels with different AMDrelated outcomes (right panel). $* * *(\mathrm{P}$-value $<0.001)$.

Figure 4. A two-sample MR analysis of the 28 AMD-associated proteins. The causal estimate (red squares) from the two-sample MR analysis compared to the observational estimates (circles) for each of the five proteins with cis-acting instruments and associated with AMD in the observational study. As each protein could have different observational coefficients depending on which definition of AMD (see Methods) was used, it was decided to select and display the coefficient for each definition which had the lower adjusted P-value. The direction of the causal estimate and observational estimates were consistent for proteins CFHR1, CFHR5 and FUT5 and inconsistent for proteins GHR and BPIFB1. The causal estimator for CFHR1, CFHR5 and FUT5 
medRxiv preprint doi: https://doi.org/10.1101/2021.07.27.21261194; this version posted July 30, 2021. The copyright holder for this preprint (which was not certified by peer review) is the author/funder, who has granted medRxiv a license to display the preprint in perpetuity. It is made available under a CC-BY-NC-ND 4.0 International license .

was significant $(\mathrm{FDR}<0.05)$ and positive, indicating that an increase in the serum level of these

proteins increase the risk of developing AMD. $*($ FDR $<0.05)$. 
medRxiv preprint doi: https://doi.org/10.1101/2021.07.27.21261194; this version posted July 30, 2021. The copyright holder for this preprint

(which was not certified by peer review) is the author/funder, who has granted medRxiv a license to display the preprint in perpetuity.

It is made available under a CC-BY-NC-ND 4.0 International license .

\section{References}

1. Wong, W.L., et al. Global prevalence of age-related macular degeneration and disease burden projection for 2020 and 2040: a systematic review and meta-analysis. Lancet Glob Health 2, e106-116 (2014).

2. Rofagha, S., et al. Seven-year outcomes in ranibizumab-treated patients in ANCHOR, MARINA, and HORIZON: a multicenter cohort study (SEVEN-UP). Ophthalmology 120, 2292-2299 (2013).

3. Jaffe, G.J., et al. Imaging Features Associated with Progression to Geographic Atrophy in Age-Related Macular Degeneration: CAM Report 5. Ophthalmol Retina (2020).

4. Chakravarthy, U., et al. Characterizing Disease Burden and Progression of Geographic Atrophy Secondary to Age-Related Macular Degeneration. Ophthalmology 125, 842-849 (2018).

5. Edwards, A.O., et al. Complement factor $\mathrm{H}$ polymorphism and age-related macular degeneration. Science 308, 421-424 (2005).

6. Hageman, G.S., et al. A common haplotype in the complement regulatory gene factor $\mathrm{H}$ (HF1/CFH) predisposes individuals to age-related macular degeneration. Proc Natl Acad Sci U S A 102, 7227-7232 (2005).

7. Haines, J.L., et al. Complement factor $\mathrm{H}$ variant increases the risk of age-related macular degeneration. Science 308, 419-421 (2005).

8. Klein, R.J., et al. Complement factor $\mathrm{H}$ polymorphism in age-related macular degeneration. Science 308, 385-389 (2005).

9. Raychaudhuri, S., et al. A rare penetrant mutation in CFH confers high risk of age-related macular degeneration. Nat Genet 43, 1232-1236 (2011).

10. Fritsche, L.G., et al. A large genome-wide association study of age-related macular degeneration highlights contributions of rare and common variants. Nat Genet 48, 134143 (2016).

11. Emilsson, V., et al. Co-regulatory networks of human serum proteins link genetics to disease. Science 361, 769-773 (2018).

12. Lamb, J.R., Jennings, L.L., Gudmundsdottir, V., Gudnason, V. \& Emilsson, V. It's in Our Blood: A Glimpse of Personalized Medicine. Trends Mol Med (2020).

13. Geyer, P.E., et al. Plasma Proteome Profiling to detect and avoid sample-related biases in biomarker studies. EMBO Mol Med 11, e10427 (2019).

14. Enroth, S., et al. Systemic and specific effects of antihypertensive and lipid-lowering medication on plasma protein biomarkers for cardiovascular diseases. Sci Rep 8, 5531 (2018).

15. Schwenk, J.M., et al. The Human Plasma Proteome Draft of 2017: Building on the Human Plasma PeptideAtlas from Mass Spectrometry and Complementary Assays. $J$ Proteome Res 16, 4299-4310 (2017).

16. Williams, S.A., et al. Plasma protein patterns as comprehensive indicators of health. Nat Med 25, 1851-1857 (2019).

17. Lehallier, B., et al. Undulating changes in human plasma proteome profiles across the lifespan. Nat Med 25, 1843-1850 (2019).

18. Emilsson, V., Gudnason, V.\& Jennings, L.L. Predicting health and life span with the deep plasma proteome. Nat Med 25, 1815-1816 (2019). 
medRxiv preprint doi: https://doi.org/10.1101/2021.07.27.21261194; this version posted July 30, 2021. The copyright holder for this preprint

(which was not certified by peer review) is the author/funder, who has granted medRxiv a license to display the preprint in perpetuity.

It is made available under a CC-BY-NC-ND 4.0 International license .

19. Sun, B.B., et al. Genomic atlas of the human plasma proteome. Nature 558, 73-79 (2018).

20. Boyle, E.A., Li, Y.I. \& Pritchard, J.K. An Expanded View of Complex Traits: From Polygenic to Omnigenic. Cell 169, 1177-1186 (2017).

21. Zhang, B., et al. Integrated Systems Approach Identifies Genetic Nodes and Networks in Late-Onset Alzheimer's Disease. Cell 153, 707-720 (2013).

22. Schadt, E.E. Molecular networks as sensors and drivers of common human diseases. Nature 461, 218-223 (2009).

23. Emilsson, V., et al. Genetics of gene expression and its effect on disease. Nature $\mathbf{4 5 2}$, 423-U422 (2008).

24. Chen, Y.Q., et al. Variations in DNA elucidate molecular networks that cause disease. Nature 452, 429-435 (2008).

25. The GTEx Consortium atlas of genetic regulatory effects across human tissues. Science 369, 1318-1330 (2020).

26. Pool, F.M., Kiel, C., Serrano, L. \& Luthert, P.J. Repository of proposed pathways and protein-protein interaction networks in age-related macular degeneration. NPJ Aging Mech Dis 6, 2 (2020).

27. Rosenfeld, P.J. Lessons Learned From Avastin and OCT-The Great, the Good, the Bad, and the Ugly: The LXXV Edward Jackson Memorial Lecture. Am J Ophthalmol 204, 2645 (2019).

28. Wang, L., et al. Lipoprotein particles of intraocular origin in human Bruch membrane: an unusual lipid profile. Invest Ophthalmol Vis Sci 50, 870-877 (2009).

29. Hollyfield, J.G., Salomon, R.G. \& Crabb, J.W. Proteomic approaches to understanding age-related macular degeneration. Adv Exp Med Biol 533, 83-89 (2003).

30. Rudolf, M., et al. Apolipoprotein A-I Mimetic Peptide L-4F Removes Bruch's Membrane Lipids in Aged Nonhuman Primates. Invest Ophthalmol Vis Sci 60, 461-472 (2019).

31. Crabb, J.W., et al. Drusen proteome analysis: an approach to the etiology of age-related macular degeneration. Proc Natl Acad Sci U S A 99, 14682-14687 (2002).

32. Curcio, C.A., Johnson, M., Huang, J.D. \& Rudolf, M. Aging, age-related macular degeneration, and the response-to-retention of apolipoprotein B-containing lipoproteins. Prog Retin Eye Res 28, 393-422 (2009).

33. Baek, J.H., et al. Quantitative proteomic analysis of aqueous humor from patients with drusen and reticular pseudodrusen in age-related macular degeneration. BMC Ophthalmol 18, 289 (2018).

34. Alves, C.H., Fernandes, R., Santiago, A.R. \& Ambrósio, A.F. Microglia Contribution to the Regulation of the Retinal and Choroidal Vasculature in Age-Related Macular Degeneration. Cells 9(2020).

35. Suarez-Calvet, M., et al. sTREM2 cerebrospinal fluid levels are a potential biomarker for microglia activity in early-stage Alzheimer's disease and associate with neuronal injury markers. EMBO Mol Med 8, 466-476 (2016).

36. Jonsson, T., et al. Variant of TREM2 associated with the risk of Alzheimer's disease. $N$ Engl J Med 368, 107-116 (2013).

37. Martin, P.M., et al. Expression of the sodium-coupled monocarboxylate transporters SMCT1 (SLC5A8) and SMCT2 (SLC5A12) in retina. Invest Ophthalmol Vis Sci 48, 3356-3363 (2007). 
medRxiv preprint doi: https://doi.org/10.1101/2021.07.27.21261194; this version posted July 30, 2021. The copyright holder for this preprint

(which was not certified by peer review) is the author/funder, who has granted medRxiv a license to display the preprint in perpetuity.

It is made available under a CC-BY-NC-ND 4.0 International license .

38. Babu, E., et al. Transport via SLC5A8 (SMCT1) is obligatory for 2-oxothiazolidine-4carboxylate to enhance glutathione production in retinal pigment epithelial cells. Invest Ophthalmol Vis Sci 52, 5749-5757 (2011).

39. Hoffmann, T.J., et al. A large electronic-health-record-based genome-wide study of serum lipids. Nat Genet 50, 401-413 (2018).

40. Weiss, F.U., Skube, M.E. \& Lerch, M.M. Chronic pancreatitis: an update on genetic risk factors. Curr Opin Gastroenterol 34, 322-329 (2018).

41. Zhang, G., et al. Integration of metabolomics and transcriptomics revealed a fatty acid network exerting growth inhibitory effects in human pancreatic cancer. Clin Cancer Res 19, 4983-4993 (2013).

42. Tamura, K., et al. Mutations in the pancreatic secretory enzymes CPA1 and CPB1 are associated with pancreatic cancer. Proc Natl Acad Sci U S A 115, 4767-4772 (2018).

43. Teich, N., et al. Interaction between trypsinogen isoforms in genetically determined pancreatitis: mutation E79K in cationic trypsin (PRSS1) causes increased transactivation of anionic trypsinogen (PRSS2). Hum Mutat 23, 22-31 (2004).

44. Burgess, S., Dudbridge, F. \& Thompson, S.G. Combining information on multiple instrumental variables in Mendelian randomization: comparison of allele score and summarized data methods. Stat Med 35, 1880-1906 (2016).

45. Lynch, A.M., et al. Plasma Biomarkers of Reticular Pseudodrusen and the Risk of Progression to Advanced Age-Related Macular Degeneration. Translational vision science \& technology 9, 12 (2020).

46. Lynch, A.M., et al. Proteomic Profiles in Advanced Age-Related Macular Degeneration Using an Aptamer-Based Proteomic Technology. Translational vision science \& technology 8, 14 (2019).

47. Laíns, I., et al. Human Plasma Metabolomics in Age-Related Macular Degeneration: Meta-Analysis of Two Cohorts. Metabolites 9(2019).

48. Laíns, I., et al. Human Plasma Metabolomics Study across All Stages of Age-Related Macular Degeneration Identifies Potential Lipid Biomarkers. Ophthalmology 125, 245254 (2017).

49. Laíns, I., et al. Human plasma metabolomics in age-related macular degeneration (AMD) using nuclear magnetic resonance spectroscopy. PLOS ONE 12, e0177749 (2017).

50. Laíns, I., et al. Metabolomics in the study of retinal health and disease. Progress in Retinal and Eye Research 69, 57-79 (2018).

51. Jones, M.M., et al. Mitochondrial DNA haplogroups and age-related maculopathy. Arch Ophthalmol 125, 1235-1240 (2007).

52. Feher, J., et al. Mitochondrial alterations of retinal pigment epithelium in age-related macular degeneration. Neurobiol Aging 27, 983-993 (2006).

53. Udar, N., et al. Mitochondrial DNA haplogroups associated with age-related macular degeneration. Invest Ophthalmol Vis Sci 50, 2966-2974 (2009).

54. Nordgaard, C.L., Karunadharma, P.P., Feng, X., Olsen, T.W. \& Ferrington, D.A. Mitochondrial proteomics of the retinal pigment epithelium at progressive stages of agerelated macular degeneration. Invest Ophthalmol Vis Sci 49, 2848-2855 (2008).

55. Ferrington, D.A., et al. Altered bioenergetics and enhanced resistance to oxidative stress in human retinal pigment epithelial cells from donors with age-related macular degeneration. Redox Biol 13, 255-265 (2017). 
medRxiv preprint doi: https://doi.org/10.1101/2021.07.27.21261194; this version posted July 30, 2021. The copyright holder for this preprint

(which was not certified by peer review) is the author/funder, who has granted medRxiv a license to display the preprint in perpetuity. It is made available under a CC-BY-NC-ND 4.0 International license .

56. Jain, I.H., et al. Hypoxia as a therapy for mitochondrial disease. Science 352, 54-61 (2016).

57. Gospe, S.M., 3rd, et al. Photoreceptors in a mouse model of Leigh syndrome are capable of normal light-evoked signaling. J Biol Chem 294, 12432-12443 (2019).

58. Liu, L., MacKenzie, K.R., Putluri, N., Maletic-Savatic, M. \& Bellen, H.J. The GliaNeuron Lactate Shuttle and Elevated ROS Promote Lipid Synthesis in Neurons and Lipid Droplet Accumulation in Glia via APOE/D. Cell Metab 26, 719-737 e716 (2017).

59. Go, Y.M., et al. MTOR-initiated metabolic switch and degeneration in the retinal pigment epithelium. FASEB J 34, 12502-12520 (2020).

60. Zhao, C., et al. mTOR-mediated dedifferentiation of the retinal pigment epithelium initiates photoreceptor degeneration in mice. J Clin Invest 121, 369-383 (2011).

61. Huang, J., et al. Abnormal mTORC1 signaling leads to retinal pigment epithelium degeneration. Theranostics 9, 1170-1180 (2019).

62. Selman, C., et al. Ribosomal protein S6 kinase 1 signaling regulates mammalian life span. Science 326, 140-144 (2009).

63. Lopez-Otin, C., Galluzzi, L., Freije, J.M.P., Madeo, F. \& Kroemer, G. Metabolic Control of Longevity. Cell 166, 802-821 (2016).

64. Swiercz, R., Cheng, D., Kim, D. \& Bedford, M.T. Ribosomal protein rpS2 is hypomethylated in PRMT3-deficient mice. The Journal of biological chemistry 282, 16917-16923 (2007).

65. Choi, S., Jung, C.R., Kim, J.Y. \& Im, D.S. PRMT3 inhibits ubiquitination of ribosomal protein S2 and together forms an active enzyme complex. Biochim Biophys Acta 1780, 1062-1069 (2008).

66. Dionne, K.L., Bergeron, D., Landry-Voyer, A.M. \& Bachand, F. The 40S ribosomal protein uS5 (RPS2) assembles into an extraribosomal complex with human ZNF277 that competes with the PRMT3-uS5 interaction. J Biol Chem 294, 1944-1955 (2019).

67. Heesterbeek, T.J., et al. Complement Activation Levels Are Related to Disease Stage in AMD. Invest Ophthalmol Vis Sci 61, 18 (2020).

68. Cipriani, V., et al. Increased circulating levels of Factor H-Related Protein 4 are strongly associated with age-related macular degeneration. Nat Commun 11, 778 (2020).

69. Consortium, G.T. The GTEx Consortium atlas of genetic regulatory effects across human tissues. Science 369, 1318-1330 (2020).

70. Alic, L., et al. A genome-wide association study identifies key modulators of complement factor $\mathrm{H}$ binding to malondialdehyde-epitopes. Proc Natl Acad Sci U S A 117, 9942-9951 (2020).

71. Rudnick, R.B., et al. FHR5 Binds to Laminins, Uses Separate C3b and Surface-Binding Sites, and Activates Complement on Malondialdehyde-Acetaldehyde Surfaces. $J$ Immunol 200, 2280-2290 (2018).

72. Irmscher, S., et al. Serum FHR1 binding to necrotic-type cells activates monocytic inflammasome and marks necrotic sites in vasculopathies. Nat Commun 10, 2961 (2019).

73. Harris, T.B., et al. Age, Gene/Environment Susceptibility-Reykjavik Study: multidisciplinary applied phenomics. Am J Epidemiol 165, 1076-1087 (2007).

74. Jonasson, F., et al. Five-year incidence, progression, and risk factors for age-related macular degeneration: the age, gene/environment susceptibility study. Ophthalmology 121, 1766-1772 (2014). 
medRxiv preprint doi: https://doi.org/10.1101/2021.07.27.21261194; this version posted July 30, 2021. The copyright holder for this preprint

(which was not certified by peer review) is the author/funder, who has granted medRxiv a license to display the preprint in perpetuity.

It is made available under a CC-BY-NC-ND 4.0 International license .

75. Holliday, E.G., et al. Insights into the genetic architecture of early stage age-related macular degeneration: a genome-wide association study meta-analysis. PLoS One 8, e53830 (2013).

76. Gold, L., et al. Aptamer-based multiplexed proteomic technology for biomarker discovery. PLoS ONE 5, e15004 (2010).

77. Tuck, M.K., et al. Standard operating procedures for serum and plasma collection: early detection research network consensus statement standard operating procedure integration working group. J Proteome Res 8, 113-117 (2009).

78. Hathout, Y., et al. Large-scale serum protein biomarker discovery in Duchenne muscular dystrophy. Proc Natl Acad Sci U S A 112, 7153-7158 (2015).

79. Max Kuhn, K.J. Applied Predictive Modeling, (Springer, 2013).

80. Raffield, L.M., et al. Comparison of Proteomic Assessment Methods in Multiple Cohort Studies. Proteomics 20, e1900278 (2020).

81. Liew, G., Joachim, N., Mitchell, P., Burlutsky, G. \& Wang, J.J. Validating the AREDS Simplified Severity Scale of Age-Related Macular Degeneration with 5- and 10-Year Incident Data in a Population-Based Sample. Ophthalmology 123, 1874-1878 (2016).

82. Voigt, A.P., et al. Single-cell transcriptomics of the human retinal pigment epithelium and choroid in health and macular degeneration. Proc Natl Acad Sci U S A 116, 2410024107 (2019).

83. Gudjonsson, A., et al. A genome-wide association study of serum proteins reveals shared loci with common diseases. bioRxiv, 2021.2007.2002.450858 (2021).

84. Bowden, J., Davey Smith, G., Haycock, P.C. \& Burgess, S. Consistent Estimation in Mendelian Randomization with Some Invalid Instruments Using a Weighted Median Estimator. Genet Epidemiol 40, 304-314 (2016).

85. Bowden, J., Davey Smith, G. \& Burgess, S. Mendelian randomization with invalid instruments: effect estimation and bias detection through Egger regression. Int J Epidemiol 44, 512-525 (2015). 
Table 1: Serum proteins significantly associated with prevalent AMD using regression analysis

\begin{tabular}{|c|c|c|c|c|c|c|c|c|c|c|}
\hline \multirow[t]{2}{*}{ Protein } & \multirow[t]{2}{*}{ Definition* } & \multicolumn{3}{|c|}{ AMD any ${ }^{\star \star}$} & \multicolumn{3}{|c|}{ AMD early** } & \multicolumn{3}{|c|}{ AMD late ${ }^{\star \star}$} \\
\hline & & $\beta$-value & P-value & P-corr & $\beta$-value & P-value & P-corr & $\beta$-value & P-value & P-corr \\
\hline NDUFS4 & I, II & -0.298 & $1.4 \mathrm{E}-17$ & 7.3E-14 & -0.264 & $2.8 \mathrm{E}-12$ & $1.4 \mathrm{E}-08$ & -0.562 & 2.7E-14 & 1.4E-10 \\
\hline CFHR1 & $\mathrm{I}, \mathrm{II}$ & 0.495 & $7.8 \mathrm{E}-10$ & 3.9E-06 & 0.157 & 3.7E-06 & 0.01869 & 0.495 & $7.8 \mathrm{E}-10$ & 3.9E-06 \\
\hline FUT5 & $\mathrm{I}, \mathrm{II}$ & 0.180 & $3.2 \mathrm{E}-08$ & 0.00016 & 0.160 & 1.7E-06 & 0.00864 & 0.347 & 3.2E-06 & 0.01608 \\
\hline TST & I, II & -0.235 & $2.6 \mathrm{E}-11$ & 1.3E-07 & -0.218 & 8.1E-09 & 4.1E-06 & -0.353 & $1.2 \mathrm{E}-06$ & 0.00629 \\
\hline BAMBI & 1 & 0.177 & $5.0 \mathrm{E}-07$ & 0.00255 & 0.158 & $8.2 \mathrm{E}-07$ & 0.00413 & 0.138 & 0.06560 & ns \\
\hline BPIFB1 & I, II & 0.193 & 3.1E-08 & 0.00016 & 0.176 & $1.9 \mathrm{E}-06$ & 0.00980 & 0.271 & 0.00022 & ns \\
\hline CEBPB & 1 & 0.173 & $9.7 \mathrm{E}-07$ & 0.00489 & 0.171 & 2.6E-06 & 0.01432 & 0.189 & 0.01393 & ns \\
\hline ST6GALNAC1 & I & 0.161 & 1.1E-06 & 0.00591 & 0.167 & $1.1 \mathrm{E}-06$ & 0.00537 & 0.102 & ns & ns \\
\hline DLL3 & I, II & 0.193 & $1.2 \mathrm{E}-07$ & 0.00062 & 0.196 & 7.0E-07 & 0.00355 & 0.170 & 0.01847 & ns \\
\hline UTS2 & 1 & 0.158 & $4.8 \mathrm{E}-06$ & 0.02449 & 0.157 & 1.3E-05 & ns & 0.157 & 0.03319 & ns \\
\hline TNFRSF14 & 1 & 0.147 & 5.3E-06 & 0.02696 & 0.158 & 2.2E-06 & 0.01129 & 0.123 & ns & ns \\
\hline CXCL17 & 1 & 0.146 & 5.3E-06 & 0.02700 & 0.145 & $1.2 \mathrm{E}-05$ & ns & 0.138 & 0.03687 & ns \\
\hline RGS8 & 1 & 0.149 & $5.4 \mathrm{E}-06$ & 0.02762 & 0.153 & 7.4E-06 & 0.03761 & 0.137 & 0.04946 & ns \\
\hline RAB17 & 1 & 0.152 & 7.1E-06 & 0.03613 & 0.147 & $2.5 \mathrm{E}-05$ & ns & 0.186 & 0.01027 & ns \\
\hline HNRNPC & 1 & 0.143 & $7.4 \mathrm{E}-06$ & 0.03769 & 0.137 & $3.0 \mathrm{E}-05$ & ns & 0.163 & 0.01434 & ns \\
\hline CRABP1 & 1 & 0.156 & 8.7E-06 & 0.04415 & 0.159 & $9.5 \mathrm{E}-06$ & 0.04829 & 0.148 & ns & ns \\
\hline CFHR5 & I, II & 0.397 & 3.2E-07 & 0.00160 & 0.077 & 0.01843 & ns & 0.397 & 3.2E-07 & 0.00160 \\
\hline RPS6KB1 & II & 0.177 & 1.1E-06 & 0.00538 & 0.172 & $7.8 \mathrm{E}-06$ & 0.03962 & 0.155 & 0.02414 & ns \\
\hline ZPBP & II & 0.178 & 8.0E-06 & 0.04075 & 0.155 & 2.6E-05 & ns & 0.171 & 0.02920 & ns \\
\hline KREMEN2 & II & 0.151 & $3.2 \mathrm{E}-05$ & ns & 0.188 & 7.3E-06 & 0.03729 & 0.168 & 0.03047 & ns \\
\hline CCL1 & 1 & 0.142 & $1.8 \mathrm{E}-05$ & ns & 0.154 & 7.4E-06 & 0.03761 & 0.177 & 0.01066 & ns \\
\hline CFP & II & -0.158 & 1.07E-05 & 0.04427 & -0.103 & 0.00079 & ns & -0.043 & ns & ns \\
\hline GHR & II & -0.156 & $1.06 \mathrm{E}-05$ & 0.04343 & -0.072 & 0.02341 & ns & -0.145 & 0.02935 & ns \\
\hline LINGO1 & II & 0.162 & 8.0E-06 & 0.04065 & 0.120 & 0.00051 & ns & 0.172 & 0.01456 & ns \\
\hline B3GNT6 & I & 0.142 & $1.0 \mathrm{E}-05$ & 0.04302 & 0.104 & 7.2E-04 & ns & 0.121 & ns & ns \\
\hline C2orf40 & 1 & 0.142 & $1.18 \mathrm{E}-05$ & 0.04882 & 0.118 & $1.5 \mathrm{E}-04$ & ns & 0.075 & ns & ns \\
\hline BCL2L1 & 1 & 0.147 & 1.16E-05 & 0.04782 & 0.127 & 4.9E-05 & ns & 0.049 & ns & ns \\
\hline BIRC2 & 1 & 0.107 & 0.00057 & ns & 0.086 & 0.00693 & ns & 0.321 & $5.0 \mathrm{E}-06$ & 0.02635 \\
\hline
\end{tabular}


Table 2: AMD-associated proteins affected by AMD risk variants

\begin{tabular}{|c|c|c|c|c|c|}
\hline \multirow[t]{2}{*}{ Protein } & \multicolumn{2}{|l|}{ AMD variant* } & \multicolumn{3}{|c|}{ Effect of variant on serum protein } \\
\hline & SNP & Most proximal gene & $\beta$-value & P-value & PQTL \\
\hline \multirow[t]{2}{*}{ NDUFS4 } & rs10922109 & $\mathrm{CFH}$ & 0.5854 & $9.86 \mathrm{E}-214$ & Trans \\
\hline & rs570618 & $\mathrm{CFH}$ & -0.8904 & $1.00 \mathrm{E}-305$ & Trans \\
\hline \multirow[t]{2}{*}{ CFHR1 } & rs10922109 & $\mathrm{CFH}$ & -0.5848 & 1.16E-234 & Cis \\
\hline & rs570618 & $\mathrm{CFH}$ & 0.4675 & $1.37 \mathrm{E}-139$ & Cis \\
\hline FUT5 & rs12019136 & FUT6 & -0.9998 & $6.51 \mathrm{E}-86$ & Cis \\
\hline \multirow[t]{2}{*}{ TST } & rs10922109 & $\mathrm{CFH}$ & 0.5241 & $3.69 \mathrm{E}-169$ & Trans \\
\hline & rs570618 & $\mathrm{CFH}$ & -0.7866 & $1.00 \mathrm{E}-301$ & Trans \\
\hline BAMBI & rs570618 & $\mathrm{CFH}$ & 0.1364 & $1.03 \mathrm{E}-14$ & Trans \\
\hline BPIFB1 & None & N/A & N/A & N/A & N/A \\
\hline CEBPB & rs570618 & $\mathrm{CFH}$ & 0.09588 & 4.59E-08 & Trans \\
\hline \multirow[t]{3}{*}{ ST6GALNAC1 } & rs10922109 & $\mathrm{CFH}$ & -0.1018 & $3.12 \mathrm{E}-08$ & Trans \\
\hline & rs570618 & $\mathrm{CFH}$ & 0.1488 & $2.00 \mathrm{E}-15$ & Trans \\
\hline & rs11080055 & TMEM97 & -0.2254 & 7.21E-37 & Trans \\
\hline \multirow[t]{2}{*}{ DLL3 } & rs10922109 & $\mathrm{CFH}$ & -0.1219 & $1.98 \mathrm{E}-11$ & Trans \\
\hline & rs570618 & $\mathrm{CFH}$ & 0.1593 & $7.24 \mathrm{E}-18$ & Trans \\
\hline \multirow[t]{2}{*}{ UTS2 } & rs570618 & $\mathrm{CFH}$ & 0.1301 & $3.88 \mathrm{E}-13$ & Trans \\
\hline & rs11080055 & TMEM97 & -0.1874 & $3.84 \mathrm{E}-28$ & Trans \\
\hline \multirow[t]{2}{*}{ TNFRSF14 } & rs570618 & $\mathrm{CFH}$ & 0.1272 & $2.14 \mathrm{E}-11$ & Trans \\
\hline & rs2230199 & $\mathrm{C} 3$ & 0.1693 & $3.96 \mathrm{E}-17$ & Trans \\
\hline CXCL17 & None & N/A & N/A & N/A & N/A \\
\hline RGS8 & rs570618 & $\mathrm{CFH}$ & 0.1711 & $7.43 E-20$ & Trans \\
\hline RAB17 & rs570618 & $\mathrm{CFH}$ & 0.1631 & $6.24 \mathrm{E}-19$ & Trans \\
\hline HNRNPC & rs11080055 & TMEM97 & -0.09574 & $2.18 \mathrm{E}-07$ & Trans \\
\hline \multirow[t]{2}{*}{ CRABP1 } & rs570618 & $\mathrm{CFH}$ & 0.1003 & $1.74 \mathrm{E}-08$ & Trans \\
\hline & rs11080055 & TMEM97 & -0.1854 & $5.16 \mathrm{E}-28$ & Trans \\
\hline CFHR5 & rs570618 & $\mathrm{CFH}$ & 0.2284 & 4.53E-32 & Cis \\
\hline RPS6KB1 & None & N/A & N/A & N/A & N/A \\
\hline \multirow[t]{2}{*}{ ZPBP } & rs570618 & $\mathrm{CFH}$ & 0.1016 & 3.81E-09 & Trans \\
\hline & rs11080055 & TMEM97 & -0.1301 & $2.27 \mathrm{E}-15$ & Trans \\
\hline KREMEN2 & rs570618 & $\mathrm{CFH}$ & 0.08655 & $3.55 \mathrm{E}-07$ & Trans \\
\hline CCL1 & rs570618 & $\mathrm{CFH}$ & 0.182 & $1.71 \mathrm{E}-22$ & Trans \\
\hline \multirow[t]{2}{*}{ CFP } & rs10922109 & $\mathrm{CFH}$ & 0.305 & 2.64E-62 & Trans \\
\hline & rs570618 & $\mathrm{CFH}$ & -0.303 & $3.82 E-59$ & Trans \\
\hline GHR & None & N/A & N/A & N/A & N/A \\
\hline LINGO1 & None & $N / A$ & $N / A$ & N/A & $\mathrm{N} / \mathrm{A}$ \\
\hline B3GNT6 & None & N/A & N/A & N/A & N/A \\
\hline \multirow[t]{2}{*}{ C2orf40 } & rs570618 & $\mathrm{CFH}$ & 0.1704 & 4.25E-19 & Trans \\
\hline & rs11080055 & TMEM97 & -0.1099 & 1.68E-09 & Trans \\
\hline BCL2L1 & rs570618 & $\mathrm{CFH}$ & 0.1611 & $3.94 \mathrm{E}-18$ & Trans \\
\hline BIRC2 & rs429358 & APOE & -0.5793 & $1.54 \mathrm{E}-106$ & Trans \\
\hline
\end{tabular}

${ }^{*}$ AMD associated variants from Fritsche et al. (PMID: 26691988)

N/A, not applicable 
medRxiv preprint doi: https://doi.org/10.1101/2021.07.27.21261194; this version posted July 30, 2021. The copyright holder for this preprint (which was not certified by peer review) is the author/funder, who has granted medRxiv a license to display the preprint in perpetuity.

It is made available under a CC-BY-NC-ND 4.0 International license .

a

AMD early

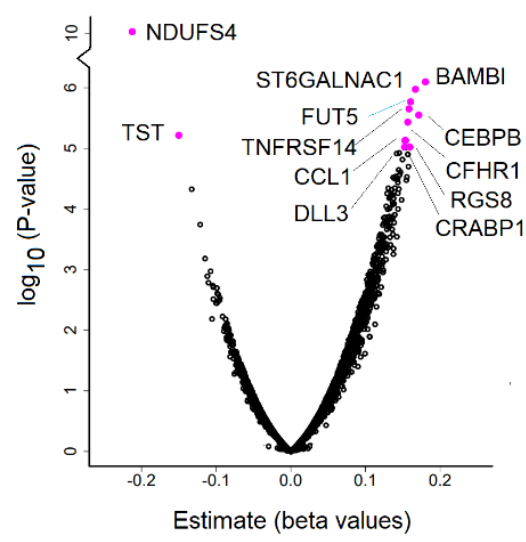

d

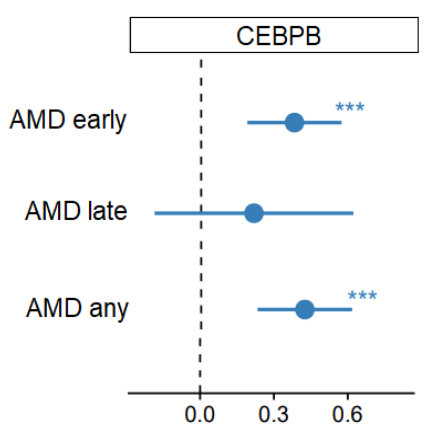

Means $\beta(95 \% \mathrm{Cls})$ b

$\underline{\text { AMD late }}$

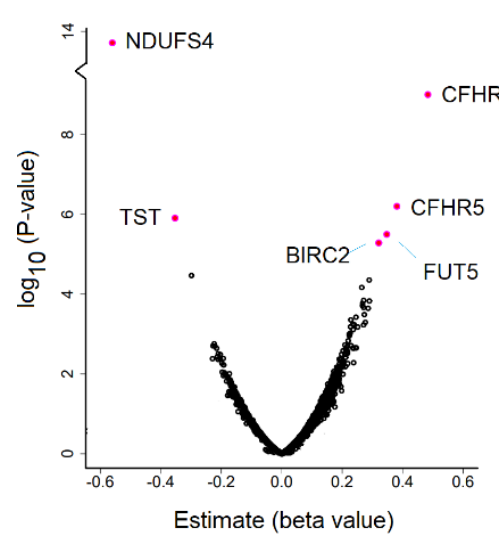

e
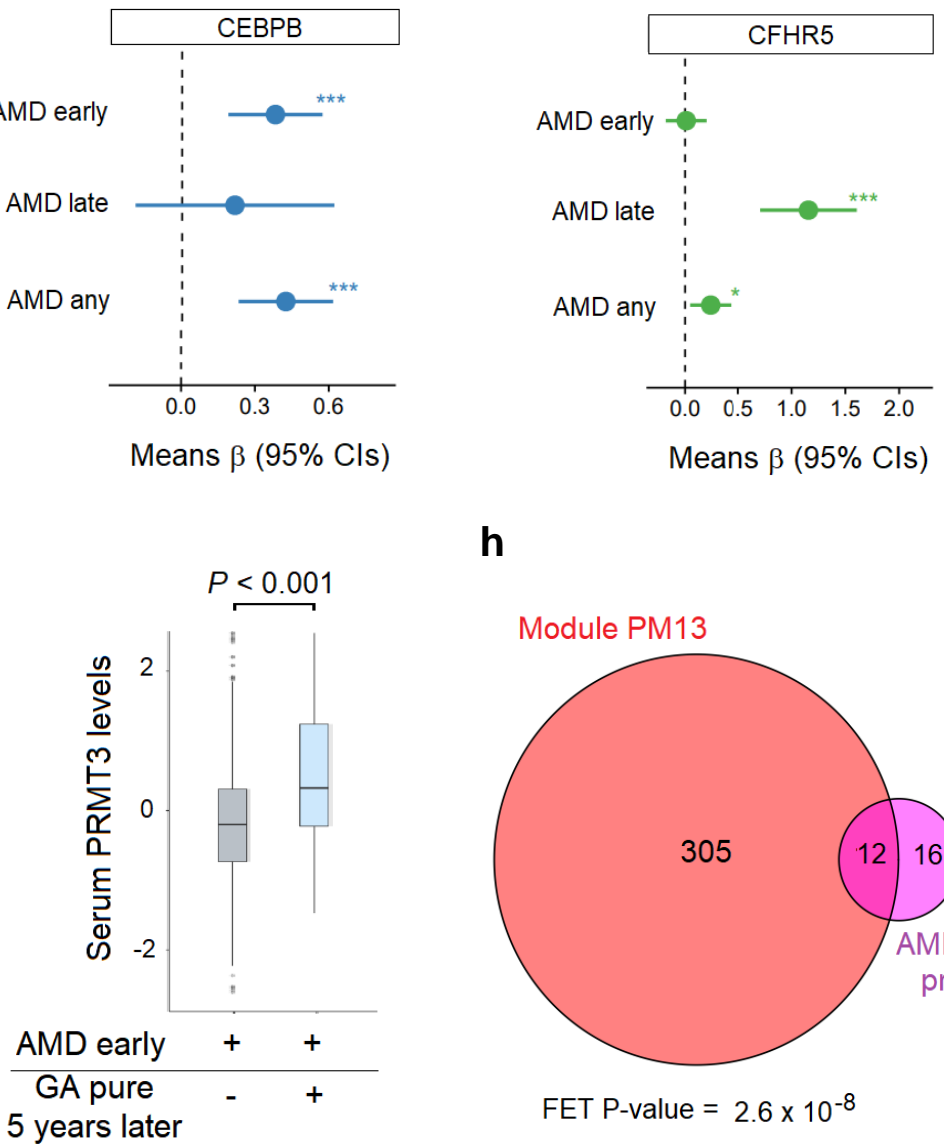

h

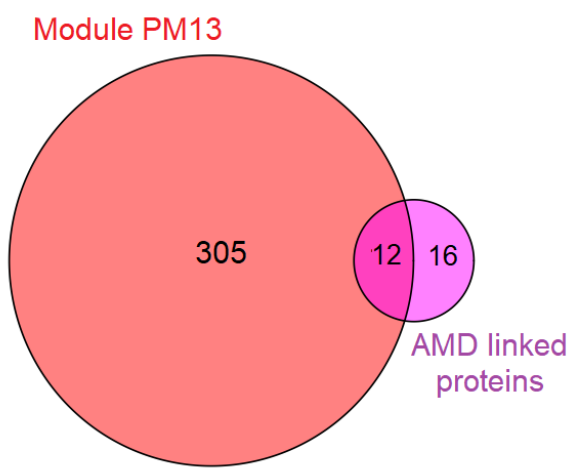

FET P-value $=2.6 \times 10^{-8}$
C

\section{AMD any}

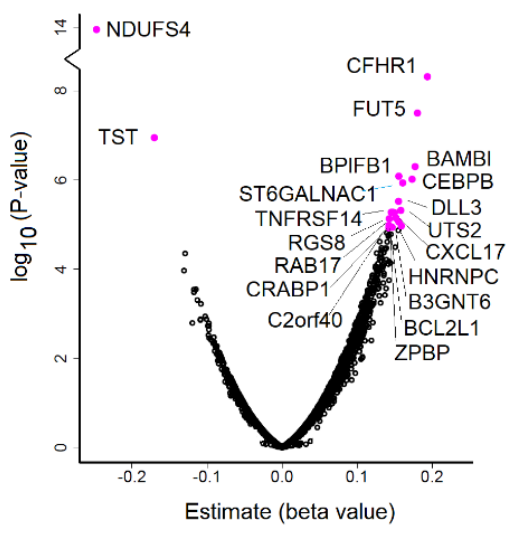

f

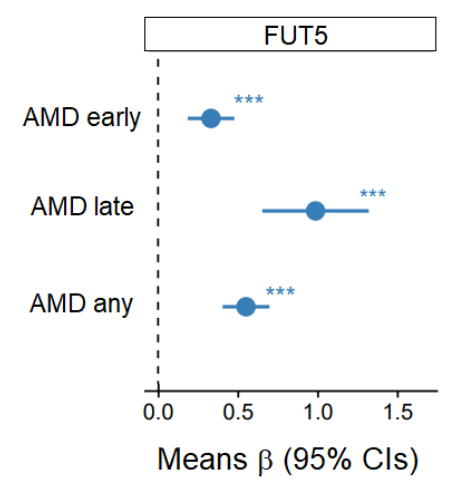

i

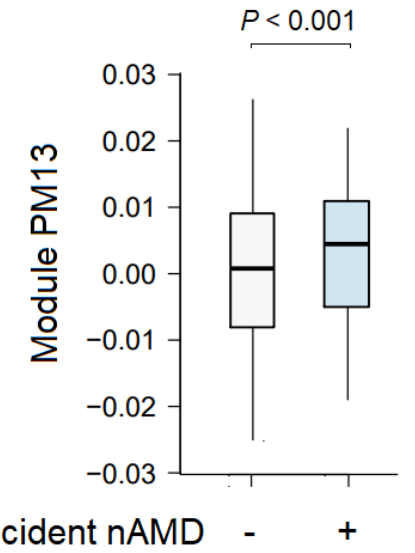

Figure 1 
medRxiv preprint doi: https://doi.org/10.1101/2021.07.27.21261194; this version posted July 30, 2021. The copyright holder for this preprint (which was not certified by peer review) is the author/funder, who has granted medRxiv a license to display the preprint in perpetuity.

It is made available under a CC-BY-NC-ND 4.0 International license .

a

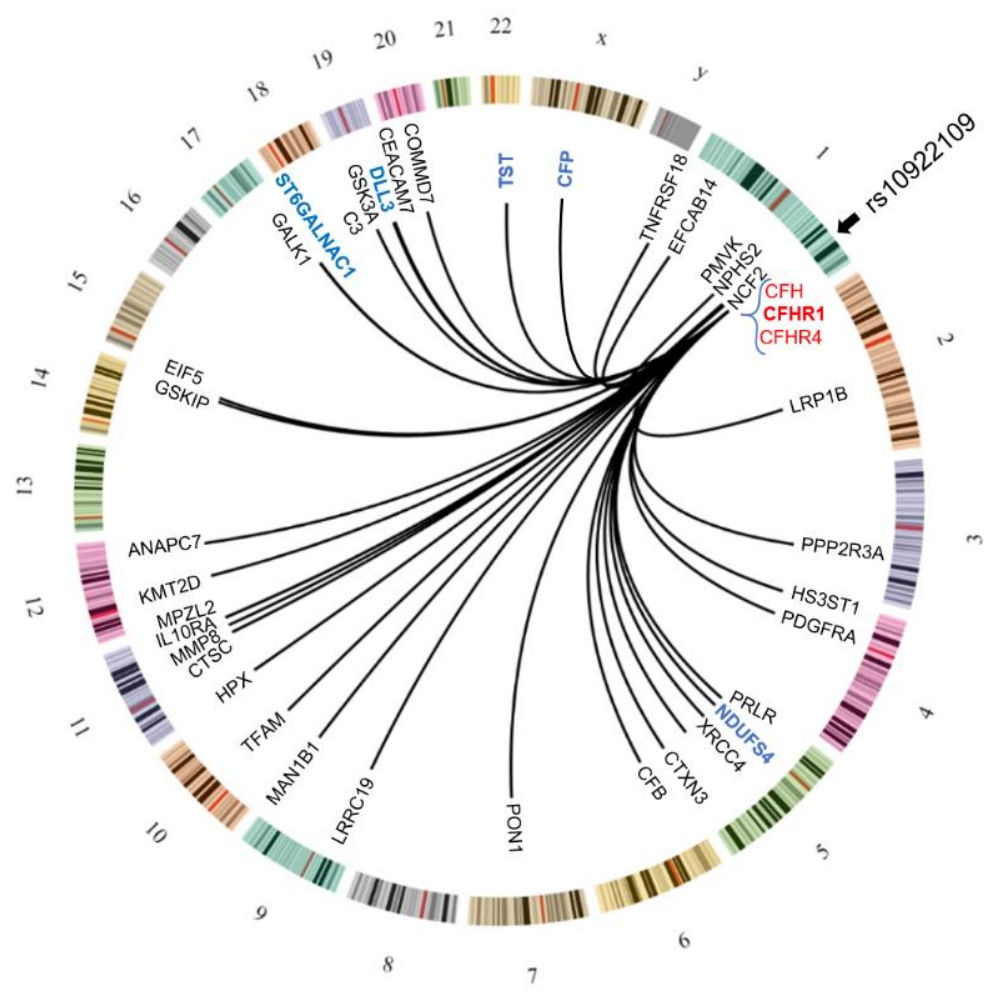

b

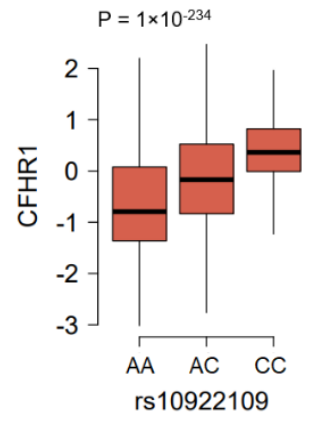

d

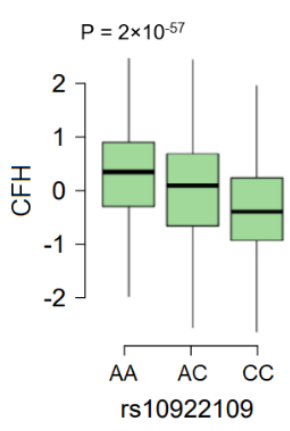

C
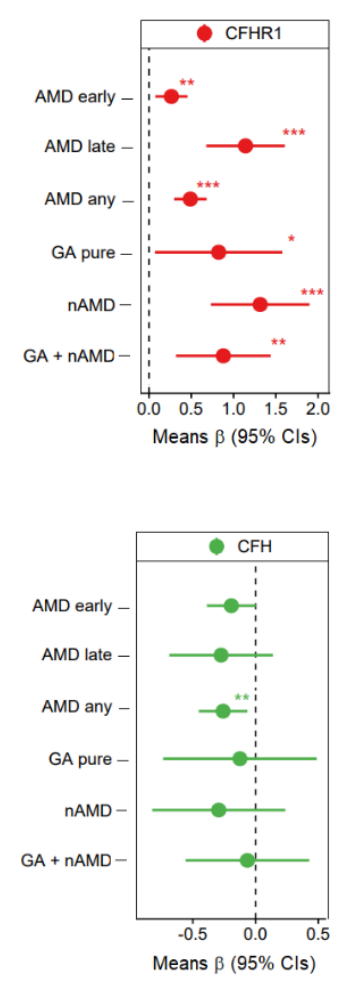

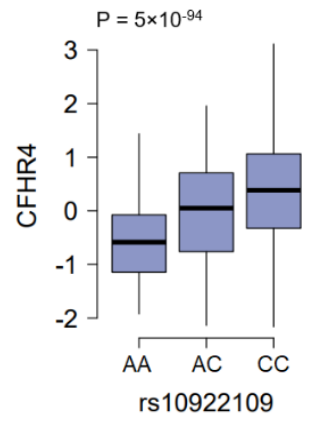

e

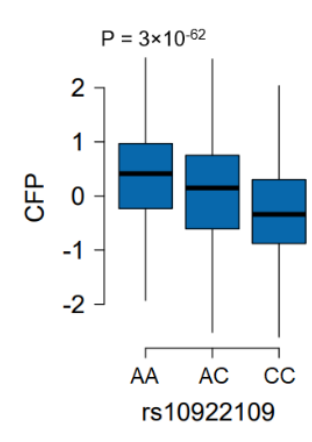

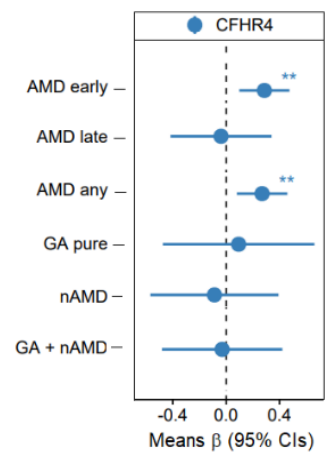

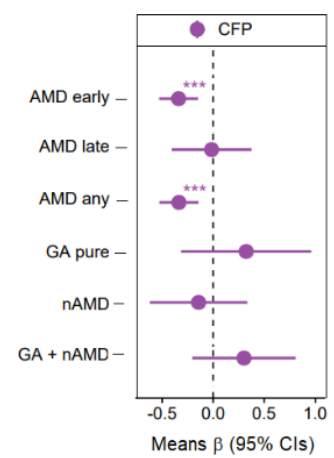

Figure 2 
medRxiv preprint doi: https://doi.org/10.1101/2021.07.27.21261194; this version posted July 30, 2021. The copyright holder for this preprint (which was not certified by peer review) is the author/funder, who has granted medRxiv a license to display the preprint in perpetuity.

It is made available under a CC-BY-NC-ND 4.0 International license .

a

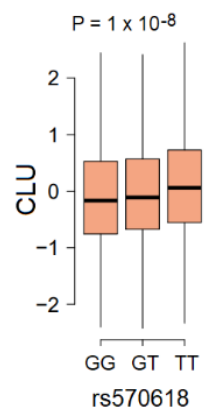

d
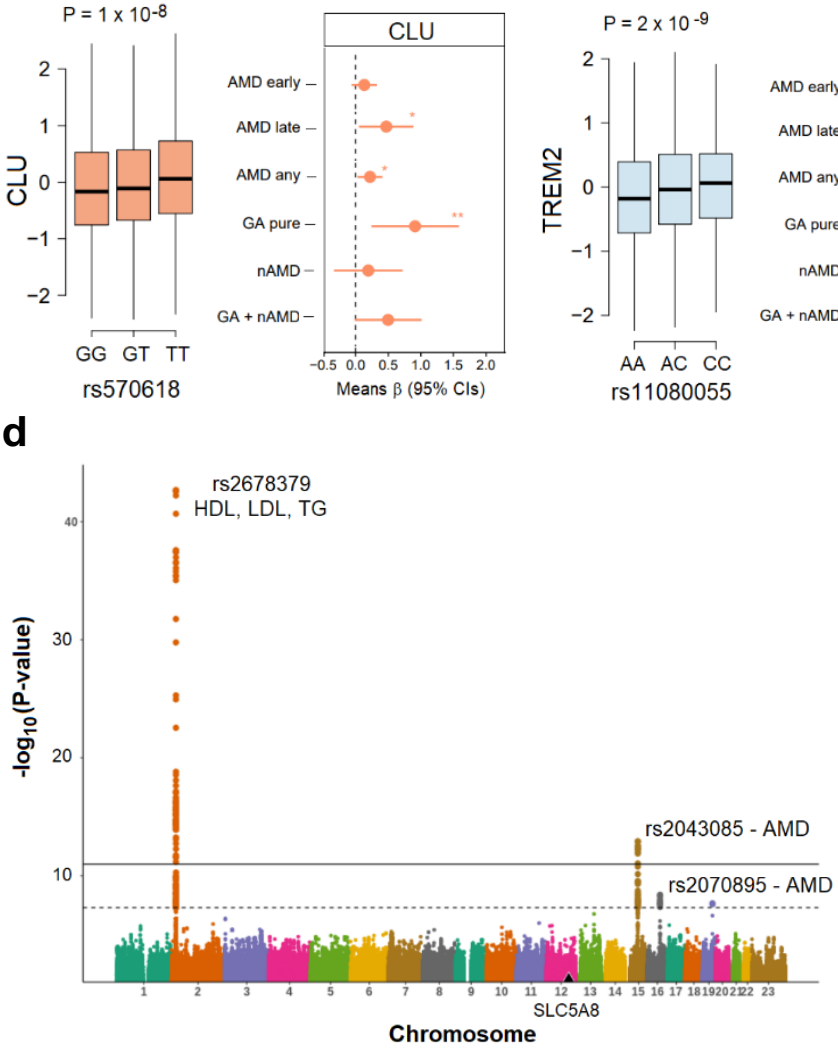

C
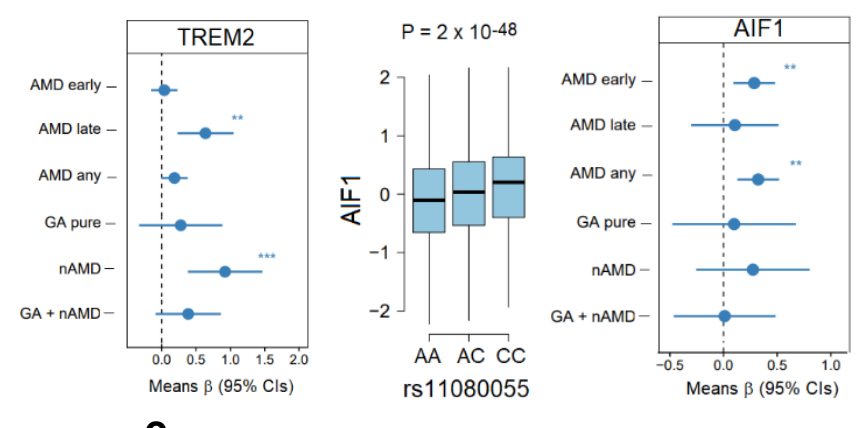

e
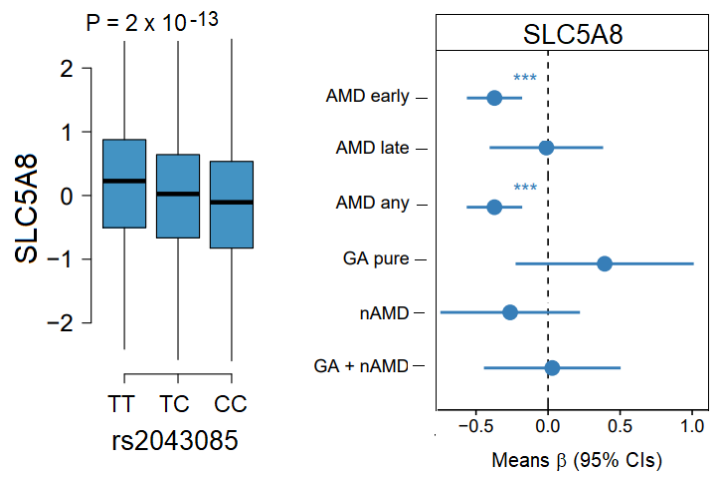

Figure 3 
medRxiv preprint doi: https://doi.org/10.1101/2021.07.27.21261194; this version posted July 30, 2021. The copyright holder for this preprint (which was not certified by peer review) is the author/funder, who has granted medRxiv a license to display the preprint in perpetuity.

\section{It is made available under a CC-BY-NC-ND 4.0 International license .}

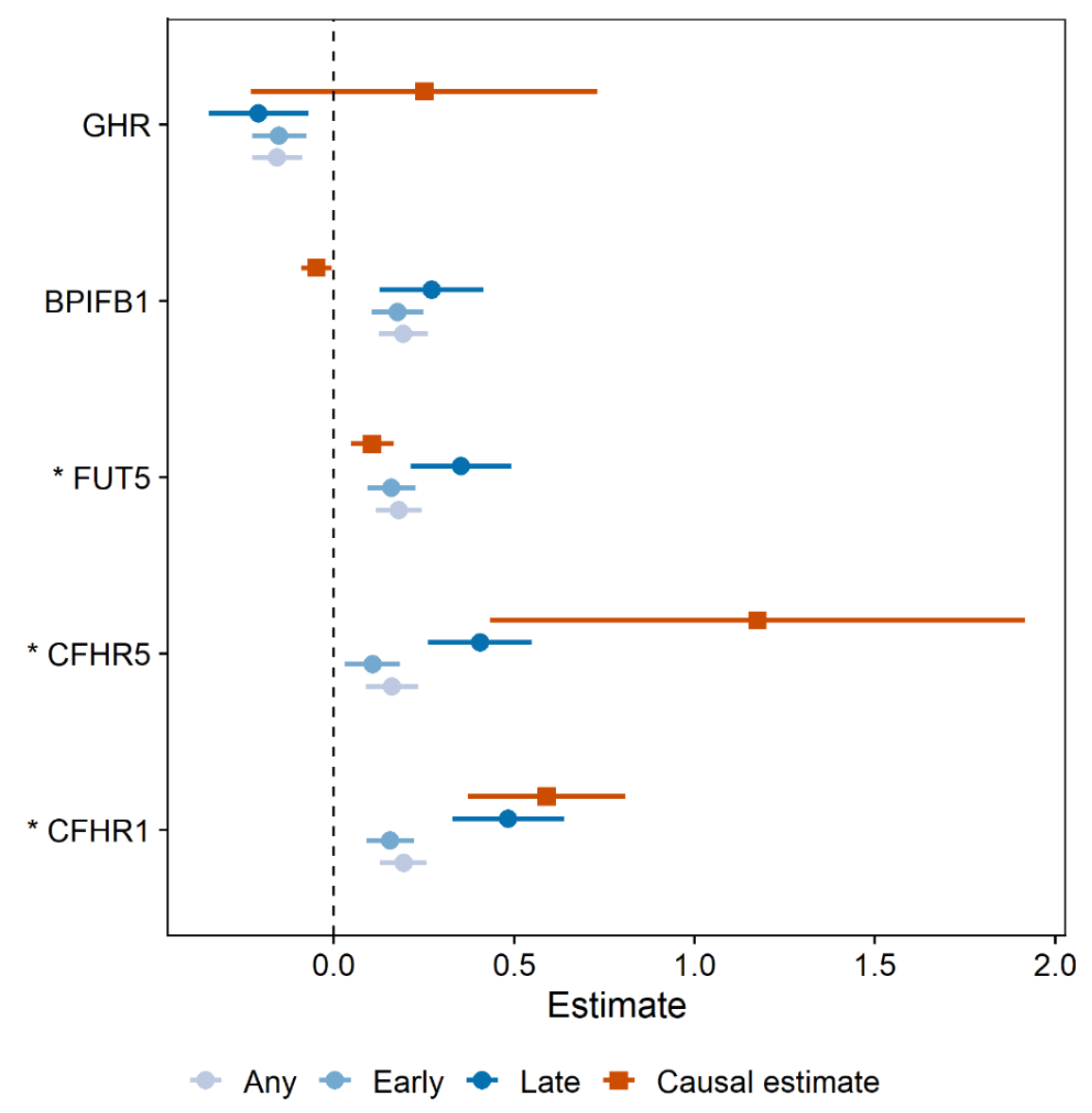

Figure 4 